[Vol.108

\title{
NOTE
}

\section{PRESSURES IN THE PROCESS OF ADMINISTRATIVE DECISION : A STUDY OF HIGHWAY LOCATION *}

\section{INTRODUCTION}

In an urban area ${ }^{1}$ location and construction of modern highways can have a marked effect upon the entire structure of the metropolitan region. A system of major arterial and circumferential highways, ${ }^{2}$ by easing the flow of traffic, provides countervailing impetuses for commercial and industrial development in both center city and suburban interchange. ${ }^{3}$ It accen-

* This Note is the result of a field study made possible by a grant from the Thomas Skelton Harrison Foundation, supplemented by funds provided by the Institute of Legal Research of the University of Pennsylvania. It is another in a series of summer research projects undertaken by members of the staff of the University of Pennsylvania Law Review and the student body of the Law School under the direction of the Review. This project was carried out by three researchers.

After a review of all available documentary material, interviews were conducted with officials of the United States Bureau of Public Roads, a former State Representative, the Pennsylvania Department of Highways, local officials of surrounding governmental bodies, the Philadelphia, Bucks County, Delaware County (indirectly via transcript of an interview not conducted by these researchers) and Montgomery County Planning Commissions, the Philadelphia Department of Streets, the Philadelphia Urban Traffic and Transportation Board, the Philadelphia Redevelopment Authority, the Philadelphia Citizens' Council on City Planning, the Philadelphia City Council, Keystone Automobile Club, the Greater Philadelphia Chamber of Commerce, the Greater Philadelphia Movement, the Delaware Valley Council, as well as former officials of these agencies, consulting engineers, leaders of groups that were formed in reaction to proposed highway locations, reporters and private individuals. This listing is not intended to indicate the approval by any of these organizations of the conclusions which this Note reaches. The authors would like to express their appreciation to everyone interviewed for his cooperation and interest.

1 Throughout this Note the term "urban" is used to denote an area of substantial population density, not necessarily confined to the boundaries of a municipality. "Rural" is used as descriptive of an area of sparse population which includes waste land as well as farming regions.

2 The modern concept of highway location is the development of urban areas in the form of a wagon wheel with multiple concentric rims. The spoke highways are termed "radials" or "arterials" and the several rims are termed "circumferentials."

${ }^{3}$ For a discussion of highway impact upon metropolitan regions see Owen, Citres in the Motor Age 63, 64 (1959); Howard, Tomorrow's Fighways, 47 NaT'L MuNrc. REv. 378, 379 (1958). An excellent example of the changes caused by an interchange is provided by King of Prussia, Upper Merion Township, Pennsylvania, an interchange discussed in Lubar, Interchange Ahead, Fortune, Oct. 1958, p. 131. The Pennsylvania Turnpike and the Schuylkill Expressway, a direct limited access route to center city Philadelphia, join nearby. Since the opening of the highways, five new industrial plants have begun operations, three are in the process of construction, and at least three more are presently planned. Interview With Local Official, Aug. 12, 1959. In addition, plans for a 400,000 square foot shopping center are well under way. Upper Merion Twp., Pa., Comprehensive Plan, Report No. 1, April 15,1959, p. 33 . Serious consideration has been given to constructing large apartment buildings in the area since travel to the city now takes only 25 to 30 minutes. Interview With Local Official, Aug. 12, 1959. 
tuates the population growth trend out from the urban core, ${ }^{4}$ particularly evidenced by the development of complexes around the interchanges on new expressways. ${ }^{5}$ Residents encouraged by rapid access to suburban lands move out from congested downtown areas ; ${ }^{6}$ lighter industry, stimulated by the availability of sizeable lots for larger plant, adequate parking grounds and expansion space, all in more attractive surroundings, burgeons near these interchanges. ${ }^{7}$ Highway location and design, too, can have their substantial effects upon the cultural character of settled communities. A major limited access highway ${ }^{8}$ can effectively separate two formerly contiguous and socio-economically linked areas-a consequence which contemporary highway planners use to advantage, making highways the buffer zones between segments of differing land use. ${ }^{9}$ Location and design, if improperly conceived, can by creating hazards and nuisances destroy the attractive features of a neighborhood, depressing land values and bringing blight. ${ }^{10}$ In contrast, proper location and design, while serving the primary

4 In Upper Merion Township, Pennsylvania, see note 3 supra, population figures from 1930 to 1950 showed an average annual increase of approximately twenty-six persons per year. Since the advent of the Schuylkill Expressway, the increase has been approximately one thousand persons per year, and between two and three hundred new homes are being constructed annually. Upper Merion Twp., Pa., Comprehensive Plan, Report No. 1, April 15, 1959, p. 10.

5 See note 4 supra. Four housing subdivisions have come into existence near the interchange since its location was finally set. Interview With Local Official, Aug. 12, 1959.

6 Owen, op. cit. supra note 3, at 88. The construction of the Schuylkill Expressway has reduced the time of travel from parts of Lower Merion Township, Pennsylvania, to center city Philadelphia from an earlier 20 or 25 minutes to a present ten or twelve minutes. Interview With Local Official, Aug. 10, 1959. See also Edwards, Kelcey \& Beck, Preliminary Planning of the Delaware Expressway, Phase I, p. 101 (1956).

7 It has been suggested that the cumulative effect of the development around interchanges first of industrial plants, then of residential and commercial uses, will eventually be an urban area extending unbroken along the length of highways in the Interstate System across the entire eastern part of the country. Cities as Long as Highways-That's America of the Future, U.S. News \& World Report, April 5, 1957 , p. 27.

8 A limited access highway is one in which the state controls and limits points of entrance and exit. In the Pennsylvania Limited Access Highway Act, PA. STAT. ANN., tit. 36, $\$ 2391.1-2391.15$ (Supp. 1958), it is defined as "a public highway to which owners or occupants of abutting property or the traveling public have no right of ingress or egress to, from or across such highway, except as may be provided by the authorities responsible therefor." PA. STAT. ANN., tit. 36, \$2391.1 (Supp. 1958). The usual practice is to limit access to interchanges and to eliminate all grade crossings. It is estimated that the first traffic light on a highway reduces the capacity of the highway by twenty per cent. Interview With Consulting Engineer, in Philadelphia, Aug. 4, 1959.

o OwEN, op. cit. supra note 3, at 51-53, 89; Howard, supra note 3, at 378, 381.

10 There have been complaints about the Roosevelt Boulevard Extension of the Schuylkill Expressway, a spur across the city of Philadelphia, to the effect that property values along the path of the highway have declined, and that the local people no longer make an effort to keep their homes attractive because of the rupture caused by the highway. At portions which are elevated, complaints have been made that drunks loiter about and both insult and assault passing women. Interview With a Local Resident, Aug. 14, 1959. In an attempt to eliminate some of the problems involving the vacant area beneath the elevated portions, the legislature enacted provisions authorizing paving, lighting and parking in the space beneath elevated limited access highways. Pa. Laws 1959, act 109. The President of the Philadelphia City 
purpose of moving traffic efficiently and economically through a region, may furnish the stimulus for elimination of existing blighted areas. Another significant impact of highways consists in the possible withdrawal of land which provides tax revenue, often in substantial amounts. ${ }^{11}$ Yet a well planned highway may improve the tax structure of the community by attracting new industry with its attendant income. ${ }^{12}$

Effects of the highway in a less highly developed area, if not as vast, may be more graphic. Cutting a highway through a relatively. small community may cause it to blossom or to change its character completely. ${ }^{13}$ Bypassing a community whose commercial life was formerly dependent upon a through highway can create a ghost town. ${ }^{14}$ Destruction of scenic countrysides by highways and the often accompanying rash of billboards has been a recent subject of concern. ${ }^{15}$

Council called for action to "heal the scars" caused by the viaduct, enumerating, inter alia, the blighting effect on neighborhoods adjacent to accumulations of mud and rubble under the road. Plans to establish parking areas were also disclosed. Philadelphia Evening Bulletin, July 14, 1959, p. 46, col. 4.

One consultant interviewed indicated that proper design, wider rights of way, and appropriate roadside planning can eliminate any problems created by noise and fumes. Interview, Aug. 4, 1959. A former state highway official believed that one of the principal features of highway design currently overlooked in Pennsylvania is proper landscaping. Interview, Aug. 14, 1959. Note that the federal-aid act expressly provides for landscaping. 23 U.S.C. \$ 319 (1958).

11 It is reported that ninety-seven organizations in San Francisco protested the construction of any new freeways, inter alia, because the land taken had formerly provided substantial tax revenues and its loss increased the tax burden. Newsweek, Feb. 16, 1959, p. 35 . The same complaint was voiced in Philadelphia. Interviews With Local Citizens, Aug. 5, 14, 1959. At a March 27, 1958 public hearing on the Delaware Expressway in Bucks County, Pennsylvania, local officials complained of the effect of the proposed route in taking needed taxable land. Interview With Local Official, Aug. 26, 1959.

12 In Upper Merion Township, Pennsylvania, where since the advent of the Schuylkill Expressway the rate of increase of land assessment values has been accelerating, most of the increase has been residential and tax rates have been raised to provide for additional necessary services. Upper Merion Twp., Comprehensive Plan, Report No. 1, April 15, 1959, pp. 6-9. However, by 1962 or 1963 new industrial plants are expected to relieve the burden of the tax bill. As against a total assessment of $\$ 28,049,900$ in 1958 , there are in direct contemplation enough plants to increase the tax base by an estimated assessed valuation of $\$ 20$ million. Interview With Local Official, Aug. 12, 1959.

13 See, e.g., a description of the effect of a Boston circumferential highway on several of the outlying "bedroom" communities, New England Highrway Upsets Old Way of Life, Business Week, May 14, 1956, p. 186. One of the proposed routes of the Mid-County Expressway would virtually destroy the Borough of Rutledge which covers an area of .17 of a square mile. The borough consists of one church, one school, one firehouse, a post office and nine streets, one of which would be completely obliterated by the highway. Philadelphia Sunday Bulletin, July 14, 1957, p. 19, col. 1 .

${ }^{14}$ Cf. Who'll Get Helped or Hurt by Auto Freeways, U.S. News \& World Report, Dec. 21,1956 , p. 90 ("service" community of 362 people succeed in preventing a proposed by-pass of their community even though the by-pass has been estimated to provide a $\$ 193,000$ saving over a twenty-year period).

15 See note 32 infra. See also Moses, The New Super-Highways: Blessing or Blight?, Harper's Magazine, Dec. 1956, p. 213. At a hearing held in Philadelphia on June 17, 1959, regarding a proposed Gustine Lake Interchange, numerous individuals criticized the highway plans as failing to recognize and preserve the scenic beauty of a local valley. More particularly, there was strong criticism directed to the proposed partial destruction of a natural landmark, Point of Rock. 
These varying and substantial consequences place upon government, which has traditionally been charged with responsibility for the administration of highway programs, ${ }^{16}$ an obligation of foresight and of sensitive awareness to competing pressures. One primary opposition is the almost inevitable competition between the needs of the community for adequate highways and the interest of the individual whose home or place of business may be taken-an interest more immediate and dramatic than that touched by any other general governmental function, even taxing. The multiple economic and sociological side-effects of highway location arouse sharply adverse demands from differently affected private groups. The manner of resolution of these conflicts in the process of decision which determines the location of a highway is critical, both for the optimal placing of the highway itself and for the esteem of governmental authority among the citizens.

This Note is limited to an examination of that process of decision from the time the idea for a specific highway is conceived until the location and design are finally determined. The questions which it asks concern the operation of the system in practice: how does the actual way in which locational decisions are made comport, on the one hand, with the legislative and administrative provisions intended to regulate the process and with the policies apparent in them and, on the other, with a realization of whatever degree of participation by private interests may be deemed appropriate? ${ }^{17}$ The method of the Note is largely empirical, drawing upon a field study conducted primarily within the Philadelphia metropolitan area during the summer of 1959.18 The geographical restriction of the study and the limited availability of comparable information from other regions has resulted in some bias toward major urban highways, ${ }^{19}$ and most of the material in the Note will relate to such highways. When other types are being considered or discussed, they will be indicated.

16 See note 59 infra.

17 While the major thrust of this Note remains within the area of highway location, there is an aspect of the problem which is wider. In effect, the conflicts which are exemplified in this area are those which arise from the expansion of the complex functions of government and the resultant difficulty to the individual of making his voice heard and his views respected and considered.

18 In recognition of the often heated and politically shaded character of highway problems, and in a desire to get personal rather than official expressions of attitudes, the researchers determined that all interviews would be conducted "off the record." Documentation must therefore be limited to date of interview and notation of the official or private status of the person interviewed.

10 The project was divided into three case studies of local highways, three highways on the Interstate System being selected because of the more ready availability of information on such large undertakings. These were: the Schuylkill Expressway, running from the Pennsylvania Turnpike to center city Philadelphia, a highway which is substantially constructed and opened for traffic (the present average daily traffic figures on the opened portion were indicated at about 85,000 vehicles, Commissioner of Streets of Philadelphia at Public Hearing, Aug. 26, 1959) ; the Delaware Expressway, which will traverse the city of Philadelphia near the waterfront, a highway partly about to be condemned, partly in final planning stages and partly still under study; and the Mid-County Expressway, which will run from near Chester, Pennsylvania, to a connection with the Pennsylvania Turnpike or the Schuylkili Expressway, a highway which is still in the process of location (an earlier proposal was studied and rejected). Newspaper files and personal interviews were used to acquire background information on the three. 


\section{The Existing Scheme}

\section{A. Legislative Setting}

\section{Federal Level}

Congress derives its power over highways from four constitutional grants: The authorities to regulate interstate commerce, ${ }^{20}$ to establish post roads, ${ }^{21}$ and to provide by the expenditure of tax revenues for the national defense ${ }^{22}$ and general welfare, ${ }^{23}$ with the logical extensions of each grant operated by the necessary and proper clause. ${ }^{24}$ Congressional recognition of the necessity for exercising the power can be traced to federal legislation in 1802. ${ }^{25}$ However, the structure of the present scheme of federal assistance was not established until 1916, when the first Federal-Aid Road Act was enacted. ${ }^{26}$ The original intent of the federal legislation was to encourage the states to build their own highways and to effectuate the program themselves with only assistance from the federal government, ${ }^{27}$ and the

20 U.S. CoNsT. art. I, § 8, cl. 3.

21 U.S. Const. art. I, $\$ 8$, cl. 7.

22 U.S. Const. art. I, $\$ 8$, cl. 1.

23 Ibid.

24 U.S. Const. art. I, § 8, cl. 18.

25 The statute authorizing the admission of Ohio as a state provided that five per cent of the proceeds of the lands sold by Congress were to be "applied to the laying out and making public roads ... such roads to be laid out under the authority of Congress, with the consent of the several states through which the road shall pass ..." Act of April 30, 1802, ch. 40, § 7(3), 2 Stat. 173. See also Act of April 19, 1816, ch. 57, \$6(5), 3 Stat. 291 (Indiana), and Act of April 18, 1818, ch. 67, §6(3), 3 Stat. 430 (Illinois). Apparently the first road constructed by the federal government was the Cumberiand Road for which $\$ 30,000$ was appropriated in 1806 . Act of March 29,1806 , ch. 19, 2 Stat. 357.

26 Act of July 11, 1916, ch. 241, 39 Stat. 355. For a discussion of the history of the federal-aid programs and the various statutes enacted see Levin, Federal Aspects of the Interstate Highway Program, 38 NeB. L. Rev. 377 (1959). See also 1 STUDY Comm. on Federal am to Highways, Comm'n on Intergovernmental Relations, Federal Aid to Higeways 8-16 (1955); 100 Cong. Rec. 2923-25 (1954).

27 The 1916 act provided for the appropriation of federal moneys but "[the] construction work and labor done in each State [were to be] done in accordance with its laws, and under the direct supervision of the State highway department, subject to the inspection and approval of the Secretary of Agriculture . . ." Act of July 11, 1916, ch. 241, $\$ 6,39$ Stat. 358. For a discussion of the functions which the states are currently required to perform see text accompanying notes 43-50 infra.

It has been suggested that the federal-aid highway program provides a great deal of opportunity for state and local corruption, especially in connection with the states' acquisition of rights of way, 23 U.S.C. $\$ 107$ (1958); and although the federal officials attempt to maintain a close check the chances for uncovering irregularity are slight. It was reported that federal officials were disturbed. Philadelphia Inquirer, May 5 1959, p. 27 , col. 1. In this regard the Bureau of Public Roads maintains a special team which travels the country investigating any indications of improper dealings. Interview With Official of the Bureau of Public Roads, July 18, 1959. A subcommittee of the Committee on Public Works of the United States House of Representatives has been set up to check on the program and prevent "skulduggery." Philadelphia Inquirer, Oct. 16, 1959, p. 19, col. 1. 
framework of the present federal-aid statute seems to envisage that the contemporary role of federal administrative activity be limited to the exercise of a veto power when necessary to maintain high standards. ${ }^{28}$ Since 1921, provision has been made that federal aid be used to encourage the development of a national system of highways. ${ }^{29}$ Recently, under the strong influence of a report by the special Presidential Advisory Committee on a National Highway Program chaired by General Lucius Clay, ${ }^{30}$ significant changes in the procedure and scope of the program were made. ${ }^{31}$ This 1956 act was supplemented by some minor additions and changes in 1958, ${ }^{32}$ and later in that year all federal highway legislation was codified. ${ }^{33}$

In essence the federal-aid act now in force provides for three systems of highways in which the national government will participate: the National System of Interstate and Defense Highways, ${ }^{34}$ the federal-aid primary system $^{35}$ and the federal-aid secondary system. ${ }^{36}$ Additional funds are made available for urban extensions of the primary and secondary systems, ${ }^{37}$ and the administration of these two systems together with their urban extensions has been designated the "ABC" program by highway officials. The Interstate System is the major operation in process today-the federal share of funds is at the rate of ninety to the state's ten per cent ${ }^{38}$ and Congress has expressly declared that "prompt and early completion . . .

2823 U.S.C. 105 (a), (d), 106, 109 (1958).

29 The 1921 act directed the Secretary of Agriculture in granting approval to projects to give preference to those which would "expedite the completion of an adequate and connected system of highways, interstate in character." Act of Nov. 9,1921 , ch. 119, \& 6, 42 Stat. 213.

30 The committee was appointed on September 7, 1954. Hearings were held on October 7 and 8 of that year at which twenty-two organizations interested in the highway program made presentations. The report of the committee, "A 10-Year National Highway Program," was submitted in January 1955. The report has been published as H.R. Doc. No. 93, 84th Cong., 1st Sess. (1955).

31 Federal-Aid Highway Act of 1956, 70 Stat. 374-387. This act has been called a "milestone" of federal-aid highway legisiation. Levin, supra note 26 , at 380.

32 Act of Aug. 27, 1958, 72 Stat. 89. The principle changes were the adoption of the billboard provisions, $\S 122$, and the extension of the hearing provisions, $\S 13$. See note 46 infra and accompanying text. For a discussion of the billboard provisions see generally Price, Billboard Regulation Along the Interstate Highzoay System, 8 KAN. L. REv. 81 (1959) ; Powers, Control of Outdoor Advertising, 38 NEB. L. REv. 541 (1959); Comment, Outdoor Advertising Control Along the Interstate Highway System, 46 CALIF. L. REv. 796 (1958).

3323 U.S.C. $\$ \$ 101-320$ (1958). For a more detailed discussion of the features of the current legislation see Levin, supra note 26.

3423 U.S.C. $\$ 103(d)$ (1958). This system was initiated in the 1944 act. Act of Dec. 20,1944 , ch. $626, \S 7,58$ Stat. 842 .

3523 U.S.C. \&103(b) (1958). This system was initiated in the 1921 act. Act of Nov. 9, 1921, ch. 119, $\$ 6,42$ Stat. 213.

3623 U.S.C. $\$ 103$ (c) (1958). This system was initiated in the 1921 act. Act of Nov. 9, 1921, ch. 119, $\$ 6,42$ Stat. 213.

3723 U.S.C. $\$ \S 103$ (b), (c), 104(b) (3) (1958).

3823 U.S.C. $\$ 120$ (c) (1958). 
is essential to the national interest and is one of the most important objectives." 39 Federal share in the $A B C$ program is only fifty per cent. ${ }^{40}$

When Congress authorizes funds for the highway program, ${ }^{41}$ the amounts are apportioned to the states and among the systems according to intricate statutory formulae. ${ }^{42}$ The responsibility then falls upon the state governments to submit proposed programs for the use of these funds to the Secretary of Commerce "as soon as practicable." 43 After the program, which is general in form, is approved, the states proceed with the necessary steps to submit for approval by the Secretary detailed plans for each proposed project within the state-wide program. ${ }^{44}$ In the 1950 act, Congress added a provision that all project plans submitted to the Secretary involving by-passing or going through a city, town or village should be accompanied by certification that the state had either held or provided the opportunity for holding a public hearing and that the "economic effects" of the location had been considered. ${ }^{45}$ In 1958, this requirement was extended to rural areas for highways on the Interstate System. ${ }^{46}$

If all the prerequisites have then been complied with and the Secretary of Commerce approves a project "his approval . . . shall be deemed a contractual obligation of the Federal Government for the payment of its proportional contribution." 47 Shortly thereafter a formal project agreement ${ }^{48}$ is executed which includes terms relating to the overall cost, the share of that cost to be borne by the state and federal governments, ${ }^{49}$ construction and maintenance. In fact the states must bear the initial cost of each phase of the program because the federal funds are not actually turned over to the states until costs are incurred.50 Each of these steps in the process is under some pressure, for failure to arrive at a project agree-

3923 U.S.C. $\S 101$ (b) (1958).

4023 U.S.C. $\$ 120$ (a) (1958). In the Federal-Aid Highway Act of 1958, the federal share for fiscal year 1960 was raised to $66 \% 3 \%$. 72 Stat. $89, \S 2$ (d) (1958).

41 In 1956, Congress created a Highway Trust Fund to which certain revenues deriving from highway users were to be transferred. 23 U.S.C. note following $\$ 120$ (1958). It was intended to provide from this fund the moneys necessary to operate the program, but thus far the fund has not been sufficient. Wall Street Journal, March 31, 1959, p. 1, col. 1. In the 1959 session, Congress added revenues from new taxes in an attempt to achieve self-sufficiency in the fund. Act of Sept. 21, 1959, 73 Stat. 615. The 1956 act authorized the expenditure of moneys for the Interstate System for a period of thirteen years in the future, ch. $462, \S 108$ (a), 70 Stat. 378 (1956), and the 1958 codification specifically adopted "all unappropriated authorizations contained in prior Acts." 23 U.S.C. \& 102 (1958).

4223 U.S.C. $\$ 104$ (1958).

4323 U.S.C. $\$ 105$ (a) (1958).

4423 U.S.C. $\$ 106$ (1958). A project is defined as: "an undertaking to construct a particular portion of a highway." 23 U.S.C. $\$ 101$ (a) (1958).

4523 U.S.C. $\$ 128$ (a) (1958). This provision provoked discussion on the floor of the Senate regarding possible intrusion upon States' rights. 96 CoNG. REC. 13005-06 (1950).

46 Act of Aug. 27, 1958, 72 Stat. 89 (now 23 U.S.C. § 128(a) (1958)).

4723 U.S.C. \& 106 (a) (1958).

4823 U.S.C. $\S 110$ (a) (1958).

49 See notes $38-40$ supra and accompanying text.

5023 U.S.C. \$121 (1958). There is a special provision authorizing advanced payment by the federal government with reimbursement by the states. 23 U.S.C. \$124 (1958). 
ment within two years after the end of the fiscal year in which the funds are authorized ${ }^{51}$ will result in a lapse in the funds apportioned to the state. ${ }^{52}$

Several statutory standards and declarations of policy are provided to guide the Secretary of Commerce. His approval is conditioned upon his satisfaction that the highway "will adequately meet the existing and probable future traffic needs and conditions in a manner conducive to safety, durability, and economy of maintenance . . ., [that] geometric and construction standards . . . for the Interstate System shall be those approved by the Secretary in cooperation with State highway departments . . . [and] be adequate to accommodate the types and volumes of traffic forecast for the year 1975." "53 The Secretary is authorized to give priority of approval to projects "recommended as important to the national defense by the Secretary of Defense." 54 Congressional policy with respect to highways on the Interstate System is declared to be that consistent with the goals of simultaneous completion and location of interstate routes on existing highways, "local needs, to the extent practicable, suitable and feasible .. shall be given equal consideration with the needs of interstate commerce." 55

The administration of federal highway programs is the responsibility of the Bureau of Public Roads, a primary unit within the Department of Commerce. ${ }^{58}$ The Bureau is organized under the immediate direction of the Federal Highway Administrator, who is nominated by the President subject to confirmation by the Senate. ${ }^{57}$ His chief assistant is the Commissioner of Public Roads, appointed by the Secretary of Commerce. Within the organization of the Bureau there are four major sections: administration, engineering, operations and research, each having various subsections. There are thirteen regional offices having jurisdiction over various multi-state areas throughout the country, whose heads, the regional engineers, are directly responsible to the Commissioner of Public Roads. Under regional office supervision there are divisional offices located in each of the several states, which have primary responsibility for the operation of the Bureau's program within the states..$^{58}$

5123 U.S.C. \&118 (1958).

5223 U.S.C. $\$ 118(\mathrm{~b})(1958)$. When the funds apportioned to a state under the Interstate System lapse, they are immediately reapportioned among the other states. The actual statutory language is that the funds must be "expended," but expenditure is deemed to take place when the funds are covered by a formal project agreement. Ibid.

5323 U.S.C. $\$ \S 109$ (a), (b) (1958).

5423 U.S.C. $\$ 105$ (d) '(1958).

5523 U.S.C. $\$ 101$ (b) (1958).

5623 U.S.C. $\$ 303(a)$ (1958). Although the statutory language refers to the Secretary of Commerce, the Bureau of Public Roads carries out these functions. See 23 C.F.R. $\$ 1.22$ (1958). Bureau of Public Roads, Administrative Memorandum 1-10.2, Aug. 5, 1957, as amended by 1-10.2(1), March 31, 1958, 1-10.2(2), Aug. 15, 1958, 1-10.2 (3), Oct. $6,1958,1-10.2(4)$, Sept. 30 , 1959, provides for the specific delegations and subdelegations of authority within the Bureau.

5723 U.S.C. $\$ 303$ (a) (1958).

58 Organizational Chart of the Bureau of Public Roads, Sept. 10, 1958, prepared by the Department of Commerce, on file in Biddle Law Library, University of Pennsylvania. 


\section{State Level-Pennsylvania}

The states have traditionally had within their plenary governmental authority the power to construct and maintain highways. ${ }^{59}$ The Pennsylvania Constitution, which proceeds from the concept of a state retaining all powers not relinquished to the federal government, makes no express grant of authority to the state legislature to undertake these functions, although it does indicate by indirection that such authority exists. ${ }^{60}$ Yet it was not until 1911, in the Sproul Act, that a state highway system was initiated. $^{61}$ Prior to this time responsibility for the management of road systems was dispersed among various local governmental agencies, but the new system was placed under the administrative direction of the State Highway Department. ${ }^{82}$ The highways which the legislature designated state highways were to be taken over from the local units and maintained by the department. In 1931 additional responsibility was added for the construction and improvement of rural roads. ${ }^{63}$ In comparison with the 33,500-mile combined total figure for the state highway and state rural routes just after the enactment, ${ }^{64}$ the present total state highway mileage has increased to more than 46,000 miles, ${ }^{65}$ ranking Pennsylvania fourth among the states in number of miles of road for which the state has assumed direct central responsibility. ${ }^{66}$

In 1945, the Pennsylvania legislature codified the highway laws ${ }^{67}$ establishing the general state administrative structure and procedures. Although the legislature has sometimes made separate provision when undertaking programs of unusual character, ${ }^{68}$ most of the major statutory

59 South Carolina State Highway Dept. v. Barnwell Bros., 303 U.S. 177 (1938) (dictum); The Minnesota Rate Cases, 230 U.S. 352, 416 (1913) (dictum); Railroad Co. v. Maryland, 88 U.S. (21 Wall.) 456 (1874) (dictum).

60 PA. Const. art. III, $\$ 7$ (prohibiting special or local legislation authorizing highways) ; art. IX, $\S 4$ (authorizing issuance of bonds to finance highways); art. IX, $\$ 18$ (requiring highway user funds to be devoted to highway purposes); art IX, $\S 21$ (increasing amount of authorization for issuance of highway bonds).

$61 \mathrm{~Pa}$. Laws 1911, act 468.

62 The State Highway Department had been established in 1903, but its original functions were chiefly limited to the assistance of local highway officials. Pa. Laws 1903 , act 188.

${ }^{63} \mathrm{~Pa}$. Laws 1931, act 1316 (the Pinchot road program).

64 Pa. Highway Planning Comm'n, Report on Pennsylvania Highways Today and Tomorrow 2 (1950).

651957 Bureau of Public Roads Highway Statistics, table at 148. The table was issued in December 1958.

${ }^{66} \mathrm{Ibid}$. There has been continuing concern in many quarters over the wisdom of having the state responsible for so much highway mileage. The objections advanced are that some local areas are inequitably subsidized from general state funds and that the highway department is not always responsive to local highway needs. Interview With Local Official, June 16, 1959.

67 Pa. Stat. Ann. tit. 36, $\S \S 670-101$ to -1102 (Supp. 1958).

68 See, e.g., PA. Stat. ANN. tit. 36, $\$ \$ 666.1-.19$ (Supp. 1958) (Keystone Shortway Act); PA. Stat. Ann. tit. 36, $\$ \$ 2391.1-15$ (Supp. 1958) (Limited Access Highway Act). 
controls relating to Pennsylvania highways are included in this enactment. Under its provisions state highways are those for which the legislature by act of assembly has assumed responsibility, not including streets in cities which are similarly taken over unless specifically so provided. ${ }^{69}$ The usual designating act defines the two end points of the highway, perhaps several intermediate points, and gives some general description of the path to be followed. ${ }^{70}$ Specific location or relocation of highways except those in cities is to be established by the Secretary of Highways, the administrative head of the Department of Highways, with the approval of the Governor. ${ }^{71}$ The only standards provided to guide the secretary in the exercise of his discretion are that such location or relocation be made "in order to correct danger or inconvenience to the traveling public, or lessen the cost to the Commonwealth in the construction, reconstruction, or maintenance thereof." 72 Whenever location or relocation within any city except Philadelphia or Pittsburgh is contemplated, the secretary with the approval of the Governor and of the city, as evidenced by an ordinance, and subject to substantially the same statutory standards of safety, convenience and lessened expense, may determine the location. ${ }^{73}$ Whenever location within Philadelphia or Pittsburgh is contemplated; the secretary with the Governor's approval must secure the approval of the city, which in this case is evidenced by an agreement between the secretary and the city, and the city's act of entering the highway on the city plan. ${ }^{74}$ The statutory standards found in the other sections are not applicable to the secretary's discretion when he acts within the two major cities. ${ }^{75}$

69 PA. Stat. ANn. tit. 36, $\$ 670-102(1)$ (Supp. 1958). The Limited Access Highway Act authorizes the Department of Highways to condemn and construct limited access highways wherever it deems appropriate; no specific legislative approval is required. PA. Stat. ANN. tit. 36, $\$ \S 2391.2($ b), (d), 2391.8 (Supp. 1958). Since most projects of any size today are limited access, this provision places broad powers in the hands of the Secretary of Highways.

70 See, e.g., PA. Stat. ANN. tit. 36, \$961-2(22) (Supp. 1958): "Beginning on the Philadelphia City-Montgomery County line at an intersection with City Avenue near the Schuylkill River, thence in a southerly direction along the west bank of the Schuylkill River to an intersection with University Avenue near the University Bridge over the Schuylkill River, a distance of about 6.40 miles" (description of Schuylkill Expressway within Philadelphia).

71 PA. Stat. ANN. tit. 36, $\S 670-210$ (Supp. 1958). The Secretary of Highways must notify the county commissioners of any location of a highway, but this requirement is for the purpose of condemnation procedures. PA. STAT. ANN. tit. 36, $\$ 670-301$ (Supp. 1958). See generally PA. STAT. ANN. tit. 36, $\$ \$ 670-301$ to -308 (Supp. 1958). See also PA. Stat. ANN. tit. 36, $\$ 670-511$ (Supp. 1958) (boroughs).

72 Pa. Stat. Ann. tit. 36, § 670-210 (Supp. 1958). See Higeway Researce Bd., Special Report 39, Legislative Purpose in Highway Law (Nat'l Academy of Sciences-Nat'l Research Council Pub. No. 628, 1958). As of November 19, 1959, there is no longer a fixed limitation of the width of highways. $\mathrm{Pa}$. Laws 1959, act 548. One state highway official complained that the statutory width limitation operative prior to this legislation made inadequate provision for multi-lane highways. Interview, June 24, 1959.

73 Pa. Stat. AnN. tit. 36, §670-523 (Supp. 1958).

74 PA. Stat. ANn. tit. 36, $\$ \S 670-544,-545$ (Supp. 1958).

75 Ibid. 
On the fiscal side, the Pennsylvania Constitution prescribes that all funds which are derived from highway users, either through taxes or licensing fees, shall be devoted to the "construction, reconstruction, maintenance and repair of and safety on public highways" and for bridges and air facilities. ${ }^{78}$ The State Highway Law provides that all moneys received from highway users shall be paid into a Motor License Fund ${ }^{77}$ and that money when "specifically appropriated and [made] available to the department" shall be paid from the Fund. ${ }^{78}$ Once funds are appropriated to the department they are available indefinitely for highway uses; ${ }^{79}$ there is no pressure for programming them as in the case of federal appropriations. ${ }^{80}$ The State Highway Law also provides authorization for the department to take all necessary steps in order to comply with federal requirements for the receipt of federal-aid funds for projects. ${ }^{81}$

The Pennsylvania Department of Highways ${ }^{82}$ is organized under a single executive as distinct from the commission type of executive found in some other states. ${ }^{83}$ The administrative head of the department is the Secretary of Highways, ${ }^{84}$ who is appointed by the Governor with the advice and consent of two-thirds of the senate. ${ }^{85}$ Under the secretary are the chief deputy secretary and deputy secretaries in charge of administration, planning and research, and engineering, ${ }^{86}$ to the latter of whom the bulk of the

76 PA. Const. art. IX, $\$ 18$.

77 Pa. Stat. Ann. tit. 36, \$670-1001 (Supp. 1958). See also Pa. Stat. Ann. tit. 72, §3441 (1950); PA. Stat. ANN. tit. 72, §302(11) (1949).

78 Pa. Stat. Ann. tit. 36, §670-1002 (Supp. 1958). See also Pa. Stat. Ann. tit. 72, §3442 (1950). Compare PA. Star. ANN. tit. 72, $\$ \$ 2615.1-10$ (Supp. 1958) (providing for a permanent allocation of funds for local streets and roads).

79 PA. Stat. AnN. tit. 36, §670-1003 (Supp. 1958).

80 See note 52 supra and accompanying text.

81 PA. Stat. ANN. tit. 36, §670-1004 (Supp. 1958).

82 Pa. Stat. AnN. tit. 36, \$670-401 (Supp. 1958). The Pennsylvania legislature has created a State Highway and Bridge Authority as a corporate body having essentially those powers necessary to carry out the financing of highway construction by the state. PA. Stat. ANN. tit. 36, §§3601-19 (Supp. 1958). This use of the corporate device has no substantive effect on operations of the Department of Highways which functions alongside of it. The powers and duties of the department are set out in PA. STAT. ANN. tit. 71, $\$ \$ 11-519$ (1942), and $\$ \S 513,515$ (Supp. 1958).

83 Returns from a questionnaire submitted to the various state highway departments as a part of this project indicate that fourteen states operate under a single executive, twenty-two are organized under a commission-type arrangement and nine states have a hybrid with a policy making commission and a single executive or administrative officer. No data was received from five states. In those states which employ the commission, qualifications are generally imposed assuring representation from the various highway districts and the minority political party.

84 PA. STAT. ANn. tit. 71, $\$ 66$ (Supp. 1958). The powers of the Secretary of Highways are set out in PA. Stat. ANN. tit. 71, \$1376 (1942).

85 PA. Stat. AnN. tit. 71, §67 (Supp. 1958).

86 The deputies are appointed by the secretary and are authorized to exercise all the powers and have all the responsibilities of the secretary except the appointment of other deputies or other subsidiary employees or carrying out functions imposed by the Pennsylvania Constitution upon the secretary. PA. Stat. ANN. tit. 71, §73 (Supp. 1958). 
staff of the department are responsible. ${ }^{87}$ There are eleven district offices regionally located, each of which is under the supervision of a district engineer responsible to the chief deputy. ${ }^{88}$ Among the district engineer's functions are the submission to the Secretary of Highways of proposed local programs based on local needs. If the secretary approves any program concerning location, construction, reconstruction or maintenance, the district engineer has the direct responsibility either for implementing the program or for supervising its implementation where personnel other than that of the department are to carry it out. ${ }^{89}$ A special office has been created in Philadelphia manned by a deputy chief engineer whose function is to supervise the planning and construction of the Delaware Expressway, a projected interstate highway which will traverse the city. ${ }^{90}$ There are also within the department a public relations section directly responsible to the secretary 91 and a staff of assistant attorneys general who are permanently assigned to the department.

The staff of the department is not protected by any legislative civil service ${ }^{92}$ although, since 1956 , certain technical and professional personnel representing perhaps ten per cent of the department's approximately 15,000 employees, ${ }^{93}$ have been placed by administrative action under the jurisdiction of the Civil Service Commission. ${ }^{94}$ In the jobs which do not have this protection, the endorsement of the local political leader on a standard form is a prerequisite to securing employment. ${ }^{.5}$

87 Interview With State Highway Official, in Harrisburg, Pa., June 24, 1959.

88 Pa. Stat. AnN. tit. 71, §514 (1942).

89 Interviews With State Highway Officials, in Haverford, Pa., June 23, 1959, in Harrisburg, June 24, 1959, and in Haverford, Pa., July 30, 1959.

${ }^{80}$ Interviews With State Highway Officials, in Harrisburg, June 24, 1959. The appointment of a special engineer was unusual, but the complexity and the cost of the project influenced the department to attempt this unique approach. Interview With State Highway Official, in Philadelphia, Aug. 7, 1959.

01 The intention to expand these functions has been expressed. The Pennsylvania Department of Highways Reports on the Automotive Safety Foundation Study, Dec. 31, 1958, pp. 14, 15.

92 There were at least four bills introduced at the 1959 session of the legislature placing certain technical and professional personnel under the jurisdiction of the Civil Service Commission, but none has been adopted. Pa. H.R. 819, 1811, 1862, 1899 (1959).

93 Automotive Safety Foundation, Report on State Highway Policies and Practices in Pennsylvania, Aug. 1, 1958, p. 16. Because of seasonal fluctuations of highway employment, only rough estimates of the percentage of employees who are protected by civil service can be made.

94 Executive Board of the Commonwealth, Resolution, Sept. 10, 1956. Subsequent additions of categories have been made by Executive Board Resolutions dated January 8, 1957, and February 8, 1957. The Executive Board of the Commonwealth is composed of the Governor as chairman, the Attorney General, Secretary of Internal Affairs, Secretary of Banking, Secretary of Agriculture, Secretary of Highways and Secretary of Welfare. Under the scheme established by these resolutions a formal agreement was entered into by the Secretary of Highways and the Civil Service Commission.

85 Interviews With State Highway Officials, in Haverford, $\mathrm{Pa}$, June 23, 1959, and in Harrisburg, Aug. 3, 1959. 


\section{Local Level-Philadelphia}

In the city of Philadelphia all streets must be placed on the Physical Development Plan of the city ${ }^{96}$ by councilmanic ordinance. ${ }^{97}$ The Home Rule Charter directs the City Planning Commission to maintain the city plan ${ }^{98}$ and also provides that before City Council can make any changes in the plan it must consider the recommendations of the commission. ${ }^{99}$ After a street is directed by ordinance to be placed on the city plan, the Board of Surveyors has the responsibility for determining the exact location. ${ }^{100}$ There are also provisions requiring both the council and the board to hold public hearings before taking these actions. ${ }^{101}$ At this stage in the process if only a city street is contemplated, the council may direct its opening, ${ }^{102}$ and the Department of Streets proceeds with construction. If, on the other hand, a state highway is contemplated, the council must authorize the mayor and the Commissioner of Streets to enter into an agreement ${ }^{103}$ with the state Department of Highways covering construction and cost sharing. ${ }^{104}$ There are in addition several agencies in Philadelphia which have a veto power over certain aspects of streets and highways that lie within their jurisdictions. Thus, the Fairmount Park Commission has the authority to determine the location of any roadway in Fairmount Park, ${ }^{105}$ and the Art Commission must approve "the design and proposed location of any . . . bridge and its approaches . . . or other structure or fixture" 108 for which city funds are expended, and also any "structure or fixture . . . to extend over any highway . . . within the City." 107

\footnotetext{
96 Philadelphia, Pa., Home Rule Charter \$ 4-600 (1951) [hereinafter cited as Charter].

97 PA. Stat. ANN. tit. 53, $\$ 16395$ (1957). Although this section speaks only in terms of "direction" by the council, the Home Rule Charter and its Purposes indicate that, other than investigations and inquiries, all legislative action is to be in the form of an ordinance CHARTER \$2-200 (Purposes). The ordinances for the Schuylkill Expressway are PhILAdelphia, PA., ORdINANCES 893 (1950) (authorizing agreement with Department of Highways); PHIladelphia, PA., ORdinances 615 (1952) (authorizing construction).

98 CHARTER § 4600.

99 ChARTER $\$ 2-307$. The approval of the commission is presumed unless it indicates the contrary within forty-five days of the introduction of a bill relating to the plan.

100 Pa. Stat. Ann. tit. 53, §16397 (1957).

101 Pa. STAt. AnN. tit. 53, \$16396 (1957) (Board of Surveyors); Charter $\$ 2-201$ (2) (City Council). One of the opponents of the Roosevelt Boulevard Extension of the Schuylkill Expressway indicated that he thought two hearings on that highway before City Council in October 1950 were poor examples of the democratic process. He expressed the opinion that the decision had already been made by the councilmen before the hearing. Interview, Aug. 5, 1959.
}

102 Pa. Stat. AnN. tit. 53, §16415 (1957).

103 See note 74 supra and accompanying text.

104 See, e.g., Philadelphia, Pa., Ordinances 684 (1958).

105 Charter $\$ 5-602(a)$.

108 Charter $\$ 5-903(1)$ (c). The veto is by no means only a paper power. When a conflict developed over the location of a portion of the Schuylkill Expressway, after a long delay and studies and restudies of proposed alternatives it was the Art Commission which finally ended the dispute by refusing to accept the final alternate proposed by opponents. Interview With Local Official, July 29, 1959. 107 Cenarter \$ 5-903(1)(d). 


\section{B. Formulation of the Idea}

While there exist many sources of ideas relating to the location of highways and many groups and agencies who propose highways, it is practically impossible to discover the point of origin of any particular idea because the idea finally implemented is usually a product of evolution rather than creation. ${ }^{108}$ Still, as a general proposition the impetus for locating a highway comes from some type of planning agency, either governmental or private.

There are various types of planning in which highways play an integral role. Highways are only one of the myriad factors which are involved in the deliberations of an agency which undertakes to organize land usage throughout an entire region. ${ }^{109}$ There is another type of planning devoted solely to highways but which focuses on such broader aspects as evaluation of the statutory scheme, consideration of more feasible administrative organization, development of adequate design and construction standards, and research relating to safety features. ${ }^{110}$ The type of planning which is the primary concern of this section of the Note, is more immediate: it deals with the process of determining the location of particular highways.

\section{Local Level}

The process of developing the general location of highways is engaged in by numerous groups on varying levels. Those groups closest to existing conditions in any one or a few combined communities may take the form of planning commissions, interest groups which maintain a continuing active concern with highways, local government officials, formal groups of private

108 Most of the highways in the Philadelphia area can be traced to some general route appearing on the Tri-State Regional Plan prepared in 1932 by a privately financed land-use planning group. Regional Planning Federation of the Philadelphia Tri-State District, The Regional Plan of the Philadelphia Tri-State District (1932). It has been indicated that the ideas prior to that plan came in the main from private local citizens. Interview With Official of Local Civic Group, in Philadelphia, June 18, 1959. However, many of the proposals which were presented by the Tri-State plan have never been further developed, and, as to those that are currently being seriously considered, it was usually some later occurrence which provided the real impetus for proceeding. Thus, while a major highway west out of Philadelphia had been considered at this early date, it was not until the plans for the Pennsylvania Turnpike were well advanced and it became clear that the terminus of the turnpike was going to place an added burden on the already overcrowded roads leading into the city from the west, that any real progress in locating the Schuylkill Expressway-as a link from the turnpike to center city Philadelphia-was begun. Interviews With State and Local Highway Officials and Members of the Staff of Local Planning Agencies, June 23, Aug. 4, 12, 21, 1959.

109 Among the agencies of this type are the Bucks, Delaware and Montgomery County Planning Commissions and the Philadelphia City Planning Commission.

110 Exemplary of such agencies on the public level are the Office of Research of the Bureau of Public Roads and the Office of Planning and Research of the Pennsylvania Department of Highways. There is also an American Association of State Highway Officials which carries on similar activities. The Highway Research Board is a quasi-public agency under the jurisdiction of the National Academy of Sciences-National Research Council. Various private organizations such as the Automotive Safety Foundation are also active in this sphere. 
individuals who combine in reaction to earlier proposals and may formulate alternate locations, informal groups of private individuals or community leaders acting on their own initiative, and local officials of the state highway department.

\section{Planning Commissions}

In the Philadelphia metropolitan area there are planning commissions at the county, township and city levels. The Philadelphia City Planning Commission, like the other planning commissions, is an official governmental organ serving in an advisory capacity to the legislative branch in matters pertaining to highway location. ${ }^{111}$ The commission is composed of nine members ${ }^{112}$ and has a staff headed by an executive director and comporting, inter alia, engineers, land use planners, sociologists, traffic analysts and economists. ${ }^{113}$ Among the functions of City Planning is the formulation of plans for the current and long-term location and design of streets and highways within the city, ${ }^{114}$ in accord with the basic concern of optimal over-all land use. ${ }^{115}$ To carry out its functions the commission collects and analyzes statistical data relating to traffic flows and needs, conducts studies and surveys, plots general locations on maps, holds and attends both formal and informal conferences with groups representing the varied interests of the community, hires consulting engineers to make preliminary studies of major highway improvements, publishes and publicly discusses its proposals, ${ }^{116}$ and, when a proposal has undergone these various stages of examination and is deemed worthy of approval, submits it to City Council.

The procedures employed by City Planning are exemplified by the role it played in the development of the Delaware Expressway project. The first meaningful consideration of the expressway came in 1945 when an engineer of the Pennsylvania Department of Highways proposed an elevated

111 In fact, the City Planning Commission reports to the mayor who, in turn, submits its report to City Council.

112 The City Planning Commission is composed of six appointed members, at least five of whom hold no other public office, the Managing Director of the city, the Director of Finance, and the City Representative. CharTer \$3-800. The members serve without compensation. CFARTER \$3-601. 1959.

113 Interview With Official of Philadelphia City Planning Commission, June 23,

114 Charter \$ 4-600.

115 In terms of the future the commission is currently working on a plan to divide the city into sections of use and provide a coordinated system of freeways to both serve and buffer the sections. Interview With Local Planning Official, Aug. 19, 1959.

116 In 1948 the planning commission presented its plan for the Schuylkill Expressway to all interested public groups in order to ascertain views. At the same time the Citizens' Council on City Planning, see text accompanying notes 138, 139 infra, undertook a similar task with private groups. Interview With Former Planning Official, Aug. 21, 1959. Similarly, county planning groups attempt to explain and elicit views from local people, as well as to convince them of the need for through highways. Interview With County Planning Official, Sept. 10, 1959. 
expressway on Delaware Avenue in Philadelphia. ${ }^{117}$ However, problems of engineering and finance prevented any action on the proposal, and the plans lay dormant until 1950 when City Planning employed a firm of consultants to carry out a study and prepare proposed locations. ${ }^{118}$ Again the enormous cost of the projected highway, which was to cut through some of the most densely built-up sections of the city, stymied utilization of the proposals. After the consulting engineer had submitted its report, City Planning met with various civic leaders and local groups to explain what was being done. ${ }^{119}$ It determined to engage another firm of consulting engineers to conduct an economic feasibility study in light of the great expenses envisaged ${ }^{120}$ and the limited availability of federal-aid funds at that time: ${ }^{121}$ among the features evaluated were the relative merits of toll and free facilities. The report of these consultants stimulated a great deal of interest among local groups representing the varied interests of the community, although most of the discussion was devoted to the toll-versusfree dispute. The existence of a free expressway, the Schuylkill Expressway, entering the city from another direction and the reluctance of certain groups to have a toll highway constructed under any circumstances contributed to further delay. ${ }^{122}$ In June 1955 , yet another firm of consulting engineers was engaged to develop substantiation for the highway ${ }^{123}$ by appraising all the existing proposals and to present recommendations as to the most appropriate route. ${ }^{124}$ During the process of this study City Planning's staff evaluated the materials presented by the consultants and actually redesigned one section. ${ }^{125}$ Apathy toward the Delaware Expressway vanished in 1956 when the prospect of ninety per cent federal participation developed. In December 1956, the Bureau of Public Roads adopted

117 Interview With Former City Official, Aug. 14, 1959. In 1932, the Regional Plan, supra note 108, included a route approximating the present Delaware Expressway. The committees which preceded City Planning had also made a similar proposal. Interview With Leader of Interest Group, June 18, 1959.

118 On projects of smaller magnitude City Planning will undertake the preliminary studies with its own staff. For the procedure employed by consulting engineers in studying highway locations see text accompanying notes 184-213 infra.

110 Its purpose was primarily the dissemination of information, but any support engendered was, quite naturally, welcome. Interview With City Official, Nov. 27, 1959. The Bucks County Planning Commission has also spoken to various local groups. Interview, Aug. 26, 1959.

${ }^{120}$ In 1953, the costs for the 23.1 miles of the Delaware Expressway contemplated at that time were estimated at $\$ 170$ million. Madigan-Hyland, Economic Feasibility of the Delaware Expressway, Phase I, Nov. 5, 1953.

121 At that time only 50-50 federal funds were available. Act of July 11, 1916, ch. $241, \S 6,39$ Stat. 357. Appropriations for federal-aid highways in 1953 totaled only $\$ 475$ million. Act of Aug. 5, 1953, ch. 328, 67 Stat. 382.

122 Interviews With Officials of Interest Groups, June 18, July 29, 1959; Interview With Former City Official, July 31, 1959.

123 Three routes were studied: the 1945 route prepared by the state highway department engineer, the 1950 route prepared by the first consultants, and a 1955 route proposed by a city councilman. Philadelphia Mayor's Special Committee on a Delaware Expressway Program, Report, Aug. 7, 1958.

124 Interview With City Official, Aug. 19, 1959.

125 Ibid. 
the Delaware Expressway as part of the Interstate System, ${ }^{126}$ and in that same month the Department of Highways took over the expressway as a project, assuming full responsibility for location and design. ${ }^{127}$ Because this project involved a highway of extraordinary cost and physical impact, its development cannot be considered typical. The number of studies and restudies engaged in evidence the particular necessity of "building a record" in order to establish the need for the highway and to persuade the local people that dislocation was justified. Nevertheless, it does indicate many of the stages through which a highway passes in this early period and the role which City Planning plays.

In 1953, perhaps responsive to a belief that the existing facilities of City Planning were inadequate for such a task, ${ }^{128}$ City Council authorized the mayor to appoint an Urban Traffic and Transportation Board to undertake a comprehensive study of the city's long-range needs and submit a report of its findings. ${ }^{129}$ This decision, and the resulting City PlanningUTTB overlap in responsibility for developing a comprehensive transportation scheme, have been subjected to continuing criticism in certain quarters. ${ }^{130}$ Some indication of the limited role the latter agency fulfills may be found in the minimal provision made for it in the city's operating budget. ${ }^{131}$

County and township planning commissions collect data, process it and prepare tentative locations for new highways by methods similar to those of City Planning, although on a smaller scale. As the problems presented in their less urbanized regions are not as intricate, these commissions are generally able to undertake all of their studies through personnel of their own staffs, employing no consulting engineers. One of their major problems is the absolute jurisdictional limitation of their responsibility, which means that each local agency is faced by the job of planning a highway location with the two end-points completely out of its control. To eliminate this problem, the various planning agencies with adjacent jurisdictions often coordinate their efforts. ${ }^{132}$

\section{Interest Groups}

There are a considerable number of interest groups which play important roles at this early stage in the location of a highway. Many of these

${ }^{126}$ Interview With Official of Interest Group, July 29, 1959.

127 The final report of the last consultants was never submitted, and when the state began its studies, it divided the route into six sections and hired different consultants for each section. Interview With City Official, Aug. 10, 1959.

128 Interview With Former City Official, Nov. 11, 1959.

129 Philadelphia, Pa., Council Resolution 374, Dec. 17, 1953.

130 Interview With Official of Interest Group, June 15, 1959.

131 The 1959 Operating Budget for Philadelphia lists $\$ 75,795$ for the UTTB as contrasted to $\$ 535,310$ for City Planning. Philadelphia, Pa., Ordinances 1145, 1148, 1159 (1958). But see Philadelphia Housing Authority, A Citrzen's Guide To Housing 89,90 (1959).

132 Interview With Leader of Interest Group, Aug. 4, 1959; Interview With Former Planning Official, Aug. 21, 1959. 
maintain permanent staffs of representatives, some of whom are able to obtain appointment to governmental committees and agencies engaged in the early, general phase of highway planning, ${ }^{133}$ or to official or quasiofficial committees ${ }^{134}$ advisory to an administrative body directly involved in planning at the locational stage. ${ }^{135}$ The importance to the interest groups of having personnel in such positions is twofold. They are able affirmatively to represent the general interests, usually business interests, of their membership, in pushing for rapid completion of commercially advantageous highway projects. (It is important to note that, in all but the unusual case, only such general interests can be represented because the membership of these groups is so broad that supporting one location rather than another will ordinarily entail the untenable job of supporting the position of one member against that of another.) Second, they profit from their inside positions to acquire advance notice of proposed locations, allowing them a good head-start at organizing opposition or beginning the time-consuming work of independent locational studies aimed at discovering and developing support for more attractive alternative routes. Some of the groups also rely on personal contacts by their officials to keep them abreast of the current developments.

Exemplary of the types of activity carried on by interest groups of this nature are the programs of the Delaware Valley Council, the Chamber of Commerce of Greater Philadelphia, and the Keystone Automobile Club. The Delaware Valley Council has a Technical Advisory Committee on Highways which formulates proposed highway locations on a long-range basis. It holds informal discussions with representatives from all interested quarters, both public and private, at meetings where an attempt is made to achieve a free flow of ideas by treating everything said as unofficial. ${ }^{136}$ A different approach is adopted by the Chamber of Commerce of Greater Philadelphia. The Committee on Streets and Highways of the Traffic and Transportation Council of that group has published a detailed report evaluating the impact of the Interstate System on Pennsylvania in general, and on Southeastern Pennsylvania and the port of Philadelphia in particular. ${ }^{137}$ This report contains not only locational elements but economic justifications as well. The Keystone Automobile Club has a section whose responsibility includes consideration of all legislation relating to highways,

133 Interviews With Officials of Local Interest Groups, June 15, 18, 22, 1959. Some agencies in the Philadelphia area that engage in this type of planning are the Urban Traffic and Transportation Board and the Philadelphia City Planning Commission.

134 There are at least three such special committees relating to the Delaware Expressway alone: Special Advisory Committee to the Mayor, Delaware Expressway Coordinating Committee, and Technical Advisory Committee to the Philadelphia City Planning Commission.

135 Interview With Official of Interest Group, June 18, 1959.

136 Interviews With Officials of Local Planning Groups, June 15, Aug. 4, 1959.

137 Traffic \& Transportation Councti, Streets \& Highways Comm., Chamber of Commerce of Greater Phil adelphia, Pennsylvania: Keystone of the InterState Highway System (1958). 
evaluation of proposed highways and presentation of the club's position to the legislature, to public agencies and at informal meetings. These examples are in no way exhaustive either of the groups at work in the Philadelphia area or of the types of activities carried on.

There is another agency in Philadelphia that may be termed an "interest group" but which is of a character somewhat different from those just discussed. The Citizens' Council on City Planning is a nonprofit, nonpartisan organization composed of civic, community and professional groups and several hundred private individuals. It is "devoted exclusively to furthering the sound physical development of Philadelphia." ${ }^{138}$ Although its executive director carries out his functions in much the same manner as do the representatives of other interest groups, the viewpoint which he represents is that of a broad cross-section of the community rather than of a single category of special interests. ${ }^{139}$

\section{Other Groups and Individuals}

It is also conceivable that local government officials and local political party leaders, ${ }^{140}$ groups which arise in reaction to proposed locations, ${ }^{141}$ and informal groups of private individuals may play a role in this early formative stage of highway location. ${ }^{142}$ However, as a general proposition

138 1957-1958 Citizens' Council on City Planning, Ann. Rep. 4.

139 Typical of the member organizations are: Chamber of Commerce of Greater Philadelphia, Philadelphia Council of Churches, School of Fine Arts of the University of Pennsylvania, Wynnefield Residents' Association, and Laborers' District Council. 1957-1958 Citizens' Council on City Planning, Ann. Rep. 18, 19.

140 It is clear that the mayor of Philadelphia will present the city's ideas to the Department of Highways. Interviews With City Official, Aug. 12, 1959, and State Official, in Harrisburg, June 24, 1959. Also, city councilmen have proposed routes, see note 123 supra, and play roles in the formulation of ideas. Interview With a City Councilman, Aug. 10, 1959. Political influence was reportedly exerted to secure a meeting of local interest group representatives with officials of the Bureau of Public Roads in regard to the Mid-County Expressway. Interview With a Local Citizen, Aug. 7, 1959.

141 Typical of such groups are the Combined Civic Associations of Montgomery and Delaware Counties and the Civic Planning Committee of Philadelphia.

142 In New Jersey, the highway department made a policy decision to deal directly with municipal officials and not with private individuals during the preliminary stages of highway alignment. This practice forces all private complaints to be funnelled into a single governmental channel. An example of its operation was presented in one instance in which the preliminary highway plans called for considerable dislocation of individual property owners. The recommended alignment was disclosed at a meeting attended by members of the county planning board, the county's legislative representatives, freeholders (corresponding to county commissioners), the mayors of the affected municipalities and members of the press. At this meeting the broad line was disclosed and discussed. Subsequently, a newspaper series was supported by the highway department. Meetings were then arranged with the officials of each municipality with the decision whether to invite members of the press left to the local officials. By the end of this stage the broad line had been narrowed to rather specific alignments. Public hearings were then held, but the state officials had the advantage of having heard most of the objections prior to that time and were prepared to explain the decisions and selections they had made. Thus, the hearings were not particularly eventful. Address, Public Relations and the Interstate Program, by W. Carmen Davis, Director of Public Information, N.J. State Highway Department, to the American Association of State Highway Officials, Baltimore, Md., Feb. 27, 1958. 
these groups do not enter the process until a later phase because their concern is less with the general highway pattern than with the direct impacts of the road on their local area, and they are unlikely to be stimulated into action until locational plans have begun to crystallize. In view of the legislative action required to create state highways, ${ }^{143}$ the opportunities for political influence in the designation of routes seem evident. Yet many persons interviewed indicated that in actual practice the incidence of $l o g$ rolling for such purposes was relatively slight. ${ }^{144}$

The District Engineer of the Department of Highways may also be the source of ideas relating to highway location. Charged with initial responsibility for all the highways within his district, he is usually made aware through personal observation or complaints by private citizens of the needs and possibilities for improvement in the area. While his particular knowledge may sometimes lead him to make detailed proposals, the usual practice is to submit only general proposals and priorities to the central office for its initial consideration before any detailed studies are made. ${ }^{145}$

\section{State Level}

Postwar planning on a state-wide level had its first major impetus in the study and report of the legislatively-created Highway Planning Commission in 1950.146 Their report included a detailed survey of existing highways throughout the state and an "inventory of road needs," as well as detailed findings and recommendations relating to a classification of highways in terms of functions, to the problem of state versus local responsibility, and to the administration and financing of the highway program. It proposed a twelve-year plan, including a number of specific recommendations for the location of major "trunkline" highways. These proposals and recommendations, however, met with slight legislative reaction and have never been effectuated..$^{147}$

143 Pa. Stat. Ann. tit. 36, $\$ 670-102(1)$ (Supp. 1958). But see PA. Stat. Ann. tit. 36, $\$ \$ 2391.2($ b), (d), 2391.8 (Supp. 1958) (limited access highways).

144 Interviews With State Highway Officials, June 24, July 30,1959; With a Former State Highway Official, Aug. 4, 1959. A somewhat contrary view was expressed by another state highway official in an Interview, June 24, 1959.

145 Interviews With State Highway Officials, in Harrisburg, June 24, 1959, in Haverford, Pa., July 30, 1959; With Former State Highway Officials, June 17, Aug. 4, 1959. One state highway official indicated that although proposals are sometimes submitted to the district engineer by local groups, they are for the most part unhelpful because those groups are generally incapable of making the technical judgments which go into location and design of a highway. Interview in Haverford, Pa., July 30, 1959.

146 The commission was created in 1949 and directed to prepare a final report for a long-range highway program. Pa Laws 1949, act 537. The final report, submitted November 1, 1950, was entitled "Pennsylvania Highways Today and Tomorrow."

147 Upon the presentation of the report, only six bills intended to implement various of its recommendations were introduced in the state senate. The bills included one relating to highway classification, $\mathrm{Pa}$. S. 135 (1951), and another relating to the transfer of responsibility for certain roads to local officials, $\mathrm{Pa}$. S. 132 (1951). 
Insofar as the Department of Highways is concerned, location planning was formerly a function solely of the Office of Engineering. During that period, there was apparently no substantial attempt to originate new ideas or to engage in comprehensive, long-range planning. ${ }^{148}$ In 1957, there was a significant change in emphasis in the department: the Office of Planning and Research was established to replace the service unit under the chief engineer, and its superior officer was placed on the deputy secretary level. Whereas the service unit had confined its attention largely to traffic analysis and user-need justification, the Office of Planning and Research operates broadly in three functional spheres : critical appraisal of the existing highway system, urban and land-use planning in coordination with local planning groups, and advanced planning.

In performing the first function, the office maintains a road $\log$ and inventory containing records of such features as highway width, type of base, number of lanes, dates and types of construction and reconstruction, traffic volumes and accidents ${ }^{149}-\mathrm{a} \log$ which is now being expanded to include data on distances of unimpeded vision at various spots along existing highways, and percentages of grades and curvature. The office conducts traffic counts, investigations (independently of the police) of the speeds and weights of various vehicles using the state's highways, origin and destination studies, ${ }^{150}$ and analyses of potential traffic needs, including existing, naturally increasing and induced needs. The office also undertakes evaluation of all current highway location proposals.

Its second function, land-use planning, is part of a development toward more sensitive awareness of the broader impact of highways. Eventually it is intended that all programming will include land-use planning in coordination with basic traffic features. It is now recognized, for example, that there is a need for stricter control around the interchanges on limited access highways. Allowing unrestricted development around an interchange during the natural burst of growth generated by the highway can create a burden on the interchange which outstrips its capacity in a short

1 Pa. Legislative Journal 257-58 (1951). Only one of the bills, an amendment relating to the maximum width of highways, was reported out of committee. That bill was subsequently enacted into law. Pa. Laws 1951, act 427, amending PA. Stat. ANN. tit. 36, \&1901 (1942).

148 Most of the material in this paragraph is the result of an interview with a state highway official, June 24, 1959. A former state highway official indicated that there was little effort to substantiate planning by statistics prior to the formation of the Office of Planning and Research. Interview, Aug. 14, 1959.

149 To date no system has been developed for the Office of Planning and Research to get complete information relating to traffic accidents, but arrangements are underway to organize a complete compilation. Interview With State Highway Official, June 24, 1959.

${ }^{150}$ In 1957 a comprehensive plotting of the origins and destinations of traffic moving into and across the state was compiled. The results of this study are being utilized in consideration of the justification vel non of major highways being proposed by various sources. Planning Division, Pa. Dep'T of Highways, Report on MULtiple Screen Line Study To Determine State-Wide Traffic Patterns (1958). 
time. ${ }^{151}$ Setback regulations to enable necessary future expansion with least disruption are now considered an important feature of highway planning.

The office's third function, advanced planning, represents an attempt to replace with development of a comprehensive program the earlier practice of highway building by merely passive reaction to various local pressures. Indeed, one intended consequence of advanced planning is to provide the department with "objective" standards to meet the more "subjective" local proposals. In January 1959, the Office of Planning and Research published a proposed five-year plan for the Interstate System in Pennsylvania including priorities for the various projects, ${ }^{152}$ and while the plan is not being precisely followed due to delays occasioned in certain projects by unresolved local conflicts, ${ }^{153}$ the very existence of the plan and of objective means for its modification when necessary is a decided advantage over a system of continual ad hoc decision. The office is currently engaged in the development of a six-year program for the whole highway system in Pennsylvania including federal $\mathrm{ABC}$ roads and state highways. ${ }^{154}$ Considerations which it will apply include highway-user benefits, land usage and land development potential.

The office receives material assistance in the form of federal funds made available for planning and research by the Federal-Aid Highway Act. ${ }^{155}$ Its staff is composed of approximately fifty employees with backgrounds in research, engineering, planning and traffic analysis. There is a feeling that the office is currently understaffed as a result, in part, of a lack of available capable personnel and, in part, of a current austerity program in state employment generally. ${ }^{156}$

151 See Lubar, Interchange Ahead, Fortune, Oct. 1958, p. 131. Note the implications for this problem of Schmalz v. Buckingham Township Zoning Bd., $389 \mathrm{~Pa}$. 295 , 132 A.2d 233 (1957) (declaring 50-foot setback regulation in agricultural district unconstitutional as improper exercise of police power). See also, Covey, Highway Protection Through Control of Access and Roadside Development, 1959 Wrs. L. Rev. 567; Levin, Highway Zoning and Roadside Protection in Wisconsin, 1951 WrSC. L. REV. 197.

152 Office of Planning \& Research, Pa. Dep't of Highways, A Proposed Five Year Progradi for the Interstate System in Pennsylvania (1959).

153 Although the Mid-County Expressway, for example, was scheduled for the letting of bids in 1960 (ibid.), the report of the consulting engineers was not in fact expected until November 1959. Interview With Official of the Bureau of Public Roads, Aug. 3, 1959. It is highly unlikely that state and federal approval, condemnation and the letting of construction bids could all be accomplished in a oneyear period. One estimate for the time needed from the hiring of the consultant to the beginning of construction in urban areas was four to five years. Interview With State Highway Official, June 24, 1959.

154 Interview With State Highway Official, in Harrisburg, June 24, 1959.

15523 U.S.C. $\$ 307$ (c) (1958).

156 Interview With State Highway Official, in Harrisburg, June 24, 1959. Besides the impact which understaffing has on actual highway planning, the official pointed out that it also curtails the department's ability to publicize the problems which planning highway location entails and to educate the public to them. 


\section{Federal Level}

In theory, the federal government does not engage to any great extent in planning the location of highways at this early stage in the process. ${ }^{157}$ However the potential availability of substantial national financial assistance subject to a veto power in the Bureau of Public Roads make states particularly amenable to any suggestions which might be put forth by the division engineer. ${ }^{158}$ Since the engineer's staff, which is constantly moving about the state to keep check on the various existing projects, is in an excellent position to observe developing highway needs, ${ }^{159}$ it is not inconceivable that a division engineer could be the generative source for the location of a highway.

In the particular case of the Interstate System, the federal government's role in setting general locations was extremely important. ${ }^{160}$ The states submitted proposals to the Bureau of Public Roads which had developed criteria for selection. ${ }^{161}$ The Bureau then selected the routes and published a map showing the designated system of highways. ${ }^{162}$

\section{Coordination}

Various forces, among them institutional structures, common interests and efforts to advance self interests, contribute to the development of patterns of coordination among these public and private highway-centered organizations. The Bureau of Public Roads, charged by Congress with watchdoging the expenditure of federal funds, ${ }^{163}$ has found it most advisable for the efficient performance of this function not to wait until the state submits programs for approval before beginning its close cooperation with state agencies. ${ }^{164}$ In fact, the Bureau begins its active participation in the

157 According to the statutory scheme, the Secretary of Commerce is only to consider for approval the programs, 23 U.S.C. \$105(a) (1958), and projects, 23 U.S.C. $\$ 106$ (1958), submitted by state highway departments.

158 See note 58 supra and accompanying text for the structural position of the division engineer in the Bureau of Public Roads and his location in the state.

150 Interview With Official of the Bureau of Public Roads, Aug. 3, 1959.

160 Interview With Official of the Bureau of Public Roads, July 18, 1959.

161 See Levin, Federal Aspects of the Interstate Highway Program, 38 NeB. L. REv. 377, 400-403 (1958), for a discussion of the method of selection employed. See also Hearings on S. 1048, S. 1072, S. 1160, and S. 1573 Before a Subcommittee of the Senate Committee on Public Works, 84th Cong., 1st Sess. 976 (1955) ; Memorandum From the Commissioner of Public Roads to the Division Engineers of the Bureau of Public Roads, July 27, 1956.

162 A total of 39,627 miles of the authorized total of 41,000 miles have been designated. 1957 Bureau of Public Roads Highway Statistics, table at 186.

163 See 23 U.S.C. $\$ 114$ (a) (1958), providing in part that, except for the secondary system, "construction shall be subject to the inspection and approval of the Secretary." See also 23 U.S.C. $\$ 121$ (c) (1958), providing that the federal share shall be paid only after "completion of the construction has been approved by the Secretary."

164 Interviews With Officials of the Bureau of Public Roads, July 18, Aug. 3, 1959. Most of the material in the succeeding text to note 166 infra was derived from these two interviews. 
planning process at the earliest stages. Physical proximity and close contact between the personnel of the offices of the federal division engineer and the state highway department give force to a coordinated effort. ${ }^{165}$ But since the state is charged with the initial responsibility for formulating highway ideas and also because at this stage of the process there is as yet no widespread knowledge of the ideas conceived, most of the influence of the local groups on the Bureau is focused through the state highway departments and there are generally no attempts to exert influence through direct approach to the Bureau officials. ${ }^{166}$

In general the channel through which the interest groups will seek to communicate their views to the public authorities during this early period is the state district engineer, all the more so in that he, carrying responsibility for the administration of departmental policy in the local area, may well feel an obligation to sound out local sentiments, ${ }^{167}$ and will be led to confer with the groups most interested in highways. Close coordination between the interest groups and municipal-level agencies is also usual, both as a function of the power which some of the latter organs may wield at later planning stages and which may make it almost necessary that the interest groups retain continuous contacts with them, and simply as a function of the common interest of co-regionals, both seeking to advance local interests before the state department. Exact patterns of relationship of course vary greatly : while in most rural areas, for example, contact with the district engineer is very nearly the only means of access to the government's highway administration, many of the large interest groups in Philadelphia - as well as municipal officials on occasion-tend to ignore the internal organization of the state Department of Highways and to present their positions directly to the central office. ${ }^{168}$ In any event, throughout

165 In Pennsylvania there is a regular monthly meeting between the top staff of the Department of Highways and officials of the division office of the Bureau of Public Roads. More informal coordination is constant. Interview With Official of Bureau of Public Roads, Aug. 3, 1959; Interview With State Highway Official, in Harrisburg, June 24, 1959.

166 But see note 140 supra.

167 Interview With State Highway Official, in Haverford, Pa, July 30, 1959. While in earlier times the department was reluctant to look to local groups for ideas, recently a trend in the opposite direction has been noted. As a result of the change in philosophy, the municipalities in upper Montgomery County, Pennsylvania, under the guidance of the county planning commission, have formed a group of representatives to serve in an advisory capacity so that a unified picture of regional views can be presented to the department. In this way disputes among the various communities are resolved at an early stage. The method has apparently achieved some effectiveness in influencing the state as to the need for and location of relief routes for major highways. Interview With Local Planning Official, Sept. 10, 1959. The Highway Planning Commission reached the following conclusion: "State-local planning is essentially a cooperative effort and thus requires a continuing cooperation between State and local officials. Its success rests primarily on voluntary individual and group effort." It recommended that: "the State continue and expand its policy of cooperation by working out its ideas with local officials, civic planning groups, chambers of commerce and other citizen groups interested in long-range highway planning." PA. Highway Planning Comm'n, Report on Pennsylvania HighWAYS TODAY aNd TOMORROW 116 (1950).

168 Interviews With State Highway Officials, in Harrisburg, June 24, 1959; With Former State Highway Official, Aug. 4, 1959; With City Official, Aug. 12, 1959. 
this first formative phase of the process, there is invariably a close integration of efforts among all the organized groups interested in highway development.

\section{Mechanics of Location and Design}

Responsibility for the initial decision adopting the general location of a highway rests with the state Secretary of Highways, ${ }^{160}$ and so much of the highway planning process as has thus far been discussed abuts at that decision. In evaluating the various general highway proposals which, however initiated, present themselves for its consideration, the upper echelon of the highway department applies as its prime criterion the balance of cost factors (costs of land acquisition, costs of construction) against highway user needs (a term of art subsuming the process of calculation which takes account of both the relationship of existing traffic flow to the capacity of existing facilities ${ }^{170}$ and the relationship of anticipated future traffic flow, whether arising by natural expansion or engendered by the attractant forces of this or other new highway construction, to the present capacity as augmented by facilities currently under consideration). ${ }^{171}$ The data necessary to make the complex estimates involved is usually already in the hands of the department; ${ }^{172}$ where data is felt to be inadequate, often specific

160 Pa. Stat. ANn. tit. 36, §670-219 (Supp. 1958).

170 Office of Planning \& Research, Pa. Dep't of Highways, A Proposed Five Year Program for the Interstate System in Pennsylvanta (1959), uses the term "congestion warrants" to describe this determination. Congestion warrants are defined as "numerical ratings based upon a survey of the capacity and volumes of traffic on existing routes parallel to a proposed Interstate Highway."

171 Analysis of traffic flow must be made in terms which discriminate between local and through traffic. Where most traffic is "through," precise location of a route may well turn on land acquisition cost factors. But in an urban area local traffic will constitute a major potential use, and location must be determined to meet this need. That is, although in the more developed area traversed by a proposed highway the cost of the right of way is high, the alternative of moving the road out into a less densely populated area may mean that the plan is no longer justified even at the lower cost because of the lessened traffic flow. Interview With Local Planning Official, July 29, 1959.

172 The data for determination of the ratio of existing flow of traffic to capacity of existing Pennsylvania highways is being made available through the inventory which the Office of Planning and Research has been compiling. See text accompanying note 149 supra. The task in this respect is eased considerably because most new highways contemplated are merely relocations or reconstructions of existing facilities. Interview With State Highway Official, in Harrisburg, June 24, 1959. (A former highway official estimated that ninety-five per cent of highway construction is based on existing facilities. Interview, June 17, 1959.) There are also available various local and state-wide studies both of the volume of traffic flow and of the origins and destinations of traffic passing certain selected check-points. One state-wide study was completed in 1957. See note 150 supra. A 1947 compilation of traffic data had been the source of many proposed highways in the Philadelphia area. Interview With City Official, Aug. 12, 1959. Recently Pennsylvania, New Jersey and nine local counties entered into an agreement to conduct a survey and study of the transportation facts in the Philadelphia-Camden-Trenton metropolitan region. The project, known as the Penn-Jersey Transportation Study, is expected to begin data collection in February 1960. After a year of data collection, a year is to be set aside for analysis and a year for preparation of the final report. Interview With Official of the Study, Sept. 2, 1959. If, in the course of evaluating a proposal the highway 
traffic studies oriented to laying a foundation for appraisal of a single highway project will be undertaken. 173

Once the data has been gathered, the factors weighed, and a decision made that a given project merits state support, the next steps in the proceedings will depend upon the nature of the highway projected and, more important, upon the expected source of the funds required to build it. If solely state moneys are to be used, and unless a limited access facility is contemplated, ${ }^{174}$ support must be mustered in the General Assembly to have the route placed on the state highway system-a task usually accomplished through the legislative representative of the area involved. ${ }^{175}$ When federal funds are sought, the state highway department must submit the proposed project as part of a program to the Bureau of Public Roads. 176 If the Bureal approves the program, the highway department is free to begin the next stage in locating the highway.

Despite the size of the staff of the Department of Highways, ${ }^{177}$ its limited funds do not permit it to retain a sufficient force of qualified technical

department finds that no such studies are available, the district engineer can usually estimate the needs in a general location from his accumulated experience. Interviews With State Highway Official, in Harrisburg, July 30, 1959; With Former State Highway Official, June 17, 1959; With City Official, June 23, 1959.

173 Interview With State Highway Officials, in Harrisburg, June 24, July 30 , 1959. Indications were that this was the usual practice today when data on hand was deemed inadequate.

An attempt has been made to refine the rough over-all cost-need determination by the development of a subtler cost-benefit ratio which would take into the balance such factors as motor vehicle operation costs, travel time, convenience, safety and benefits to surrounding land. Interview With Consulting Engineer, Aug. 4, 1959. See American Ass'n of State Highway Offictals, Road User Benefit Analyses FOR HIrghway Improvements (1952). Regarding the Schuylkill Expressway, which was located in large part in park land inside the city of Philadelphia because this land was readily available and less expensive (Interviews With Official of Interest Group, June 18, 1959; With City Official, July 29, 1959; With Former Planning Official, Aug. 21, 1959), one local citizen expressed his opinion that the thinking of the highway officials was shortsighted. He reasoned that although the cost of the park land might be less, using the highway to clear out blighted areas would save money in the long run, while preserving the beauty of the park. Interview, Aug. 12, 1959.

174 An especially significant factor in deciding whether to reconstruct an existing highway or to lay a new one may be the desire to limit access. While it is well established that there is no right to access for which compensation must be paid when a new highway is constructed, it appears that the conversion of an existing highway to a limited access facility is a taking of an easement of access which must be compensated. Carazalla v. Wisconsin, 269 Wisc. 593, 70 N.W.2d 208 (1955). The court in this case discusses three law review articles and treats them as authoritative: Clark, The Limited Access Highway, 27 WASE. L. REV. 111 (1952); Cunnyngham, The Limited Access Highway from a Lawyer's Viezpoint, 13 Mo. L. REv. 19 (1948); Freeways and the Rights of Abutting Owners, 3 STANFORd L. Rev. 298 (1951). See Highway Researce Bd., Spectal Report No. 26, Expressway LAw (Nat'l Academy of Sciences-Nat'1 Research Council Pub. No. 482, 1957), for a survey of the state laws respecting access rights. And $c f$. Creasy v. Stevens, 160 F. Supp. 404 (W.D. Pa. 1958), rev'd on other grounds sub nom. Martin v. Creasy, 360 U.S. 219 (1959).

175 Interview With State Highway Official, in Harrisburg, June 24, 1959.

17623 U.S.C. $\$ 105$ (a) (1958).

177 See text accompanying note 93 supra. 
and professional personnel-for which it has only a fluctuating needto engage unaided in detailed location and design studies for major projects. For this purpose firms of consulting engineers are engaged by the central office in Harrisburg, ${ }^{178}$ although the district engineer, who works directly with the consultants and thus becomes somewhat familiar with their merits and qualifications, may submit recommendations with regard to specific projects. ${ }^{179}$ The consultant's contract is the product of a negotiation rather than a bidding procedure, ${ }^{180}$ a practice justified by highway officials on the grounds that it is necessary that the department remain free to select the most competent consulting engineers on the basis of its experiences with and observations of the performance of the various available firms. ${ }^{181}$ Another prevailing practice in these dealings-that of compensating the consultants on the basis of a percentage of the total cost of the projecthas been the subject of more serious dispute. ${ }^{182}$ When federal funds are to be expended to reimburse the state for its expenditures, the division engineer of the Bureau of Public Roads may be consulted in regard to the employment of any particular consultant. Even in this matter the ideas of the Bureau are sought in order to avoid later disputes as to the validity of the consultant's conclusions based on attacks upon his ability and experience. ${ }^{183}$

When a consulting engineer is employed, he will probably discuss with the district engineer of the state highway department all of the information and ideas then available. ${ }^{184} \mathrm{He}$ may likewise discuss with the local planning commissions or other agencies responsible for highways any studies which they have undertaken. ${ }^{185}$ While it is possible for the consultant to discuss

178 Interview With State Highway Official, in Harrisburg, June 24, 1959. These consulting firms are regular civil engineering firms, often with traffic engineers on their staffs. There is evidence that some expertise in highway matters is being developed, and at least one firm of traffic consultants exists in Philadelphia. 1959.

179 Interviews With State Highway Officials, in Harrisburg, June 24, July 30,

180 Ibid.

181 Ibid.

182 Concern has been expressed that this arrangement may promote a tendency in consultants to employ more expensive design standards (such as more highway lanes) than actually required. Interviews With Consulting Engineers, in New Jersey, Aug. 4, 1959, in Philadelphia, Aug. 13, 1959. One suggestion for coping with the danger is to have the department acquire the traffic data from another source, either its own staff or a different consultant, so as to possess an independent standard by which to evaluate the total cost figures and the recommendations for design and location made by the consultants. Interview With Consulting Engineer, in Philadelphia, Aug. 13, 1959. Nevertheless, since it would appear that the more efficient the consultant, the less expensive will be the project, the wisdom of compensation by commission based on total cost is in any event open to question.

183 In practice the Bureau must approve the work of the states at all stages of the process including even the department's fixing of the general outline of the route before consultants are hired. Interview With Official of the Bureau of Public Roads, in Harrisburg, Aug. 3, 1959.

184 Interviews With State Highway Officials, in Haverford, Pa., June 13, 1959; With Consulting Engineer, in Philadelphia, Aug. 13, 1959.

185 Interviews With Local Planning Officials, June 23, Aug. 19, 26, 1959; With State Highway Officials, June 23, 1959; With Local Officials of Lower Merion Twp., Pa., Aug. 10, 1959. There is some indication that this step is of recent origins. Interviews With Local Officials, Aug. 12, Sept. 2, 1959. 
with interest groups and other private parties their ideas pertaining to the location, from all indications this is seldom done. ${ }^{186}$ The initial step in determining a highway location is to establish a "desire line" ${ }^{187}$-an ideal directional path, unrelated to topography, physical structures or existing roads, that would be selected by the greatest number of motorists traveling between two end-points. ${ }^{188}$ Often the desire lines have been established by the state highway department on the basis of its traffic flow studies and are simply turned over to the consultant. ${ }^{189}$ It is the consultant's job to reconcile the theoretical summum bonum of the desire lines with pressures of physical contour, cost and the foreseeable social and economic impacts on the area to be traversed.

In rural areas typical procedure ${ }^{190}$ would be for the consultant firm to begin with a contour map and mark a broad area which seems most suitable for detailed study. ${ }^{191}$ Aerial photographs of the area provide an accurate

186 Interview With State Highway Official, July 30, 1959; Interview With Consulting Engineers, in New Jersey, Aug. 4, 1959, in Philadelphia, Aug. 13, 31, 1959. But a local planning official was of the opinion that determination of local reaction is standard practice on major freeways today. Interview, July 29, 1959. He stated that City Planning had encountered substantial problems because it had failed to assess local reactions when a firm of consultants prepared the original plans for the Roosevelt Boulevard Extension of the Schuylkill Expressway.

187 Interviews With Consulting Engineers, in New Jersey, Aug. 4, 1959, in Philadelphia, Aug. 13, 1959, in Philadelphia, Aug. 19, 1959.

188 Origin and destination studies and traffic volume studies both for the present and projected for the future are used to establish these desire lines. In fact, the lines are directional from a single point and do not originally represent paths determined by two given ends (the desire line between any two such points would always be a straight line), but once the lines are drawn a second point can be selected as a suitable end-point for a given line. This point may not be the end actually selected for a given route, because, for example, there may be two forces operating - a flow from $A$ to $B$ and one from $A$ to $C$, a point beyond $B$ but not in direct line from $A$ to $B$. The desire line might then indicate that the highway should by-pass $B$, but for practical reasons it might be decided to run it through $B$.

189 Interview With Consulting Engineer, in Philadelphia, Aug. 13, 1959.

190 One outline for the steps in location and preliminary design is as follows: "(1) Determine the approximate traffic load along a general route suggested by traffic desire lines. (2) Select the type of highway and number of lanes needed to accommodate the approximate traffic load and the type of service to be provided. (3) Make plan and field studies to establish one or more preliminary lines and profiles that approximate the desire line location, and make sketch preliminary design including interchange locations. (4) Assign traffic to one or more of the selected locations to determine design traffic volumes. (5) Adjust line and complete sketch preliminary plans for major alternate locations. (6) Analyze and compare alternate locations for selection of the preferred one by making cost estimates, analyzing road user benefits, and considering other controls and factors." AMIERICAN ASS'N OF STATE Highway Officials, A Policy on ARTertal Highways in Urban AREas, 7-8 (1957). The text continues: "The final choice of location and type of highway always cannot be achieved by orderly consideration of the separate and individual steps outlined above. Usually all steps are taken in close sequence or simultaneously and the major controls considered jointly. Often some of these steps or certain controls are fixed and the other considerations are adjusted to fit." Id. at 8.

191 The material in this paragraph was derived chiefly from interviews with consulting engineers on August 4,13, and 19, 1959. It was indicated that in most cases, both rural and urban, the alignment is substantially controlled by the topography of the land and the location of physical structures. Within any one ten-mile stretch the two end points are fixed and the leeway left to the consultants is not great. Interview With Consulting Engineer, in Philadelphia, Aug. 13, 1959. 
indication of more detailed terrain contours and location of existing physical features. Up to a dozen apparently feasible lines may be drawn on this photograph and costs of the various alternatives roughed out. While the bulk of the physically possible routes may be set aside at this stage as impracticable, usually several alternatives remain for more elaborate consideration, often involving computation of relative cost-benefit ratios. ${ }^{192}$ In practice as many as five studies, but at the least two, are conducted on a given route before it will be recommended. Procedures for locational planning in highly developed urban areas may be somewhat different from the rural model. The number of feasible alternatives will obviously be more limited. There is usually available some detailed plan or map which obviates the necessity for aerial photographs and surveys on the terrain, and detailed route proposals, perhaps even reports of previous consultants, ${ }^{193}$ are likely to exist. Otherwise the process of elimination by a series of studies of increasing detail and complexity is much the same.

The factors which a consulting engineer may consider in the location of any highway can be placed in four general classes: ${ }^{194}$ finances, design standards, economic factors and sociological considerations. ${ }^{195}$ In the finance category are the cost of right-of-way acquisition (involving questions of relative property costs, decisions to take private land as against public land if the latter is available and its taking would be feasible, perhaps availability of a cieared path such as a railroad right-of-way) ${ }^{196}$ and costs of construction (dependent, inter alia, upon topography and the necessary standard of design). The design standards category involves decisionin the light of contemplated types, numbers and origin-destination classes of vehicles which will use the facility, and of relation to existing roads ${ }^{197}$ and physical structures-of questions of highway width and curvature, fre-

192 See note 173 supra.

193 See text accompanying notes $117-127$ supra.

194 These categories have been selected by the writers for ease of presentation, and it should not be assumed that the consultants consider the factors in these terms. Some of the factors might arguably be placed in a category other than that selected, but the characterization of the factors has no significance in the process being described.

195 See, e.g., American Ass'n of State Highwax Officials, op. cit. supra note 190, at 137-38: "The worth of arterial highway improvements may be expressed in terms of benefits and advantages to the road user and the municipality, with recognition of some disadvantages or negative benefits. Items to be considered include vehicle operating costs, safety, comfort and convenience, esthetics, accessability, new development, redevelopment of blighted areas, property values, tax revenues, etc. . . . Usually, the easier flow of traffic, greater accessability, and added convenience ... benefit .. business, industry, and government . . . ."

196 One consulting engineer interviewed noted a tendency throughout the eastern part of the country to use abandoned railroad beds to obviate expensive acquisition costs. Interview, in Philadelphia, Aug. 13, 1959.

197 An example of the importance of this factor is seen in the history of the Roosevelt Boulevard Extension of the Schuylkill Expressway. Because of current traffic volumes, it was decided that the new facility must be so located as not to eliminate any major existing streets. This decision made necessary the taking of a number of homes which otherwise might have been avoided. Interview With Former Planning Official, Aug. 21, 1959. 
quency and location of interchanges or intersections, type of permissible access and possible need for ancillary feeder systems where access is controlled.198 Some of the significant elements which may be considered under the economic-impact head are reduction or accretion of the tax base, prospective growth of the area both natural and highway-induced, service of the road to existing residential, commercial and industrial needs in the area and relationship to existing land uses. Sociological considerations embrace such factors as dislocative effects, potential impact on historical monuments, cemeteries, schools and churches, and aesthetic concerns. ${ }^{190}$ In urban regions complexities in all categories are particularly compounded: 200 the consulting engineer who has decided to traverse rather than to bypass a municipality ${ }^{201}$ must worry about coordination with the existing system of local streets and with public transportation, ${ }^{202}$ relocation of residents and industries, ${ }^{203}$ avoidance of future and possible elimination

108 See note 8 supra. Because the access of property owners located adjacent to such highways is limited, it is often necessary, especially in developed areas, to build a network of local service and feeder roads to carry the traffic generated from the adjacent properties.

190 Interview With State Highway Official, in Harrisburg, June 24, 1959.

200 See the discussion of these factors in Howard, Tomorrow's Highways, 47 Nat'L MUNIC. Rev. 378 (1958).

201 See Who'll Get Helped or Hurt by Auto Freeways, U.S. News \& World Report, Dec. 21, 1956, p. 90. The author indicates that by-passing the main street of a community often works to the benefit of local merchants because local people use their shops more when the streets are not clogged with through traffic.

202 The importance of this factor is emphasized in OwEN, Citres IN THE Motor AGE 100-10 (1959); Howard, supra note 200; Fordham, Urban Renewal in Metropolitan Context, Fifth Annual Wherrett Lecture on Local Government, Institute of Local Government, University of Pittsburgh (1959). Sheer mathematical computation indicates that the development of new highways coupled with population expansion will not permit provision for center city parking to any but a limited degree. Mass transit seems the only feasible resort, and, as the authors indicate, coordination of mass transit and highways becomes essential.

203 The Pennsylvania Department of Highways has no agency that relocates persons or businesses affected by condemnation. This work is either performed by civic groups, such as the Chamber of Commerce, or by local public agencies, such as the Relocation Bureau of the Philadelphia Redevelopment Authority or the Philadelphia Industrial Development Corporation. Philadelphia is one of two cities, Cincinnati being the other, with a centralized relocation bureau. Much of the money for relocation comes from the federal government under its urban renewal program.

The Relocation Bureau of Philadelphia has relocated people whose homes lay in the path of the Roosevelt Boulevard Extension of the Schuylkill Expressway. The procedure employed is as follows: Coordination with other agencies through the Redevelopment Authority alerts the Relocation Bureau that a change in a neighborhood is contemplated which will necessitate some relocation. The bureau may enter the community as much as two years prior to condemnation and make a study of the size of families and the income of the residents. Then just prior to the actual condemnation another study is undertaken to assure that all data is correct and current. While the Relocation Bureau ascertains what types of housing will be needed, however, it must rely on local real estate agents to provide it for the bureau has authority neither to purchase nor to rent homes. Remuneration provided by the Relocation Bureau varies in form. It may be as much as $\$ 100$ moving costs for a single person or family living in a furnished apartment, or it may be a direct grant (all of the bureau's payments are outright grants, not loans) to a family living in a furnished apartment, in an amount which depends on the number of rooms. In the relocation of businesses the 
of present conditions of blight, maintenance of parking facilities and of a balanced system of open spaces. ${ }^{204}$

The inseparable interrelation of all these factors means, of course, that a condition or development within any single dimension may be related to a given highway planning decision either as cause or as effect: unwillingness to disturb an extant pattern of streets may necessitate alteration of an otherwise desirable highway location or the placing of the highway may disturb the streets. While the existence of the problem itself-the incompatability of the highway location and the street scheme-is essentially an issue of fact, the most important feature of the consultant's task is to determine the weight to be accorded that issue relative to all of the other issues of fact. His evaluative balance represents one of the most significant stages of the location procedure, for it is probably at this point of decision that for the only time throughout the entire process all of the significant factors are within the immediate knowledge of one person or small group of persons charged with the responsibility to decide. Great weight may subsequently be attached to this decision. Moreover, since it is the first time that a decision has been made, it represents the first opportunity for contention, and the fact that the decision is based on the exercise of judgment leaves that decision particularly susceptible to differences of opinion.

It should not be assumed from the preceding discussion that the consulting engineer acts alone in striking a balance and making the initial determination as to a perferred route. In fact, the consultant works closely with the district engineer of the state highway department who is also in constant contact with the central office. ${ }^{205}$ That liaison begins at the outset when the district engineer's office provides the consultant with all the information which it has available. The district engineer, who will have to submit his recommendation along with the consulting engineer's final report, has almost daily conferences with the consultant, resolving problems as they arise. $^{206}$ Likewise, whatever the more passive role seemingly envisaged by the federal statutory framework, ${ }^{207}$ the field representative of the Bureau of Public Roads keeps in close touch with the state procedures throughout this phase, with a view both to understanding all of the intermediate decisions which are made and of expressing an initial reaction.

bureau is authorized to provide up to $\$ 2,500$ for moving costs, but there is no authority for direct payment. Businesses are also assisted by the Philadelphia Industrial Development Corporation. Interview With City Official, July 24, 1959. See PrInAdelpaia Housing Ass'N, A Citizen's Gutde to Housing 53-57 (1959). See also Note, Moving Expenses in Condemnation Proceedings, 21 U. PIrT. L. REV. 97 (1959).

204 See Owen, Cities in the Motor Age 23-25 (1959).

205 Interview With State Highway Official, in Haverford, Pa., July 30, 1959. Before the addition of the Office of Planning and Research, the Department of Highways did not work too closely with the consultants, but today there is coordinated effort all along the line. Interview With Consultant, in Philadelphia, Aug. 13, 1959. 1959.

206 Interviews With State Highway Officials, in Haverford, Pa, June 23, July 30,

20723 U.S.C. $\S \S 105,106$ (1958). 
The culmination of these efforts is a determination of one, or perhaps two or three, center lines which the consultant intends to propose. Many consultants consider this point the end of the first phase of their studies. ${ }^{208}$ At this juncture it often occurs, especially when the approval of a local municipality is required ${ }^{209}$ but also as a matter of expediency in other cases, that the views of local officials are solicited. When they have been brought into the process, they may use whatever means they deem advisable to obtain other local views. In Philadelphia coordination is accomplished through the Department of Streets, which seeks the opinions of all local agencies involved, including the City Planning Commission, City Council, the Fairmount Park Commission, ${ }^{210}$ the Housing Authority, the Department of Commerce, and the Redevelopment Authority. ${ }^{211}$ On projects of considerable scope special local committees may be formed as, for example, the advisory committees to the mayor and to City Planning and the special committee of city officials, interest groups and vitally affected industries which were formed with regard to the Delaware Expressway. ${ }^{212}$

With one or a very few center lines adopted, ${ }^{213}$ the consultant is ready to begin the second phase of his study, design. In the design phase much the same factors that influence decisions on location are considered. The difference on the engineering level is clear-decisions now involve the planning of structures, points of access, interchanges or intersections, grade, curvature, number of lanes, and whether the highway is to be on grade, on fill, elevated or depressed. The mere statement of these problems indicates the added force with which certain of the surrounding factors will demand consideration as, in working out precise details, the actual effect of the highway becomes more clearly defined. The consulting engineer rightly appreciates that a difference of two degrees in the curvature of a clover leaf or five feet in the total width of the highway may cause an enormous difference in effect upon a particular property owner, especially in an urban

208 Interview With Consultant, in Philadelphia, Aug. 19, 1959. In OFFICE of Planning \& Research, Pa. Dep'T of Highways, A Proposed Five Year Program FOR THE INTERSTATE SysteM IN PENNSyLVANIA (1959), the procedure of planning is broken down into three stages: location study, preliminary design and final design. A state highway official described the various stages as general location (determining only a corridor the highway is to follow), preliminary location (fixing the location rather precisely), and exact location and design (considered as purely engineering determinations). Interview, in Harrisburg, June 24, 1959.

209 See notes 73, 74 supra and accompanying text.

210 The plans for the Schuylkill Expressway were given to the Fairmount Park Commission, and various commission members were taken over the route and shown in detail what was planned. The members were subsequently kept informed of the progress of the plans. Interview With Former City Official, Aug. 21, 1959.

211 Interview With Local Official, Aug. 12, 1959.

212 See note 134 supra. The map hammered out at the meeting of the Delaware Expressway Coordinating Committee was the same map presented at a public hearing six months later. Interview With Representative of Business, Aug. 12, 1959; Interview With City Official, Aug. 19, 1959.

213 Generally any differences which may have existed between the consultant, the Department of Highways, the Bureau of Public Roads when federal funds are involved, and perhaps even local officials are resolved at this time. 
area. After all of these critical decisions have been made, the consultant prepares a report indicating the two or more routes studied, the one he recommends and the justification for his conclusions.

\section{State's Acceptance of a Preferred Route}

When the consultant's report is submitted to the state highway department, the Deputy Secretary for Engineering, the chief deputy, and the secretary ordinarily make a decision which represents the department's preference as to the path the highway is to follow. As articulated by the American Association of State Highway Officials, this involves the "complex correlation of several controlling factors" including "anticipated traffic," "influences of commercial, industrial, residential and civic uses of land," "existing and potential sites for off-street parking," the "street system and operation thereon, including public transit," "topography and physical features," "existing utilities," and "pleasing appearance." 214 At this time the department has at its disposal the consultant's report, which includes (1) the accumulated data regarding traffic flow and estimated future traffic flow, ${ }^{215}$ topography, design, estimated right-of-way costs, ${ }^{216}$ construction costs and interference with existing land uses, (2) an evaluation of these facts by the consultant, (3) the consultant's recommendations in light of his evaluation, and (4) the consultant's justification for his proposals. The department also has the recommendation of the district office which evaluates the consultant's report from the standpoint of cost, traffic standards and design standards, ${ }^{217}$ although usually most of the ideas of the district engineer have already been incorporated in the consultant's report. 218

In making its decision, the highway department may consider the opinions and recommendations of official representatives of the local communities. ${ }^{219}$ In fact, there is some indication that until recently, in the case of outlying communities where the state statutory requirement of municipal approval for highway location is not applicable, ${ }^{220}$ the department may have neglected the views of local officials. ${ }^{221}$ But since practical

214 American Ass'n of State Highway Officials, op. cit. stupra note 190, at 6, 7. 215 The federal-aid act directs the Secretary (Bureau of Public Roads) to require design standards "adequate to accommodate the types and volumes of traffic forecast for the year 1975" for highways on the Interstate System. 23 U.S.C. § 109(b) (1958). 216 The consultants hire independent appraisers to estimate the cost of acquisition along the proposed route. Interview With State Highway Official, in Haverford, Pa., July $30,1959$.

217 Ibid.

218 Ibid.

219 The recommendations of the district engineer often deal with the reaction of the local people, with which the engineer is usually familiar. Ibid.

220 See notes 73,74 supra and accompanying text.

221 The location of the Delaware Expressway in Bucks County, Pennsylvania, provides an example. The consulting engineer on that project contacted the Bucks County Planning Commission for their views but there was never any direction or even suggestion from the highway department that this would be a wise course to follow. Interview With Local Official, Aug. 26, 1959. 
considerations make it unwise to alienate the people of an area of highway development, ${ }^{222}$ the latest policy is affirmatively to seek out local sentiments. Similarly, then, in cases where information has come to the attention of unofficial groups ${ }^{223}$ and stimulated reaction, communications from these groups will usually be considered. ${ }^{224}$ To what degree these communications -or those of local officials-will influence the final decision of the highway department is difficult to determine, especially since all the planning to this point has been devoted to the achievement of a final location which ideally would not need to be changed. ${ }^{225}$ Certain propositions can be clearly established, however: (1) to the extent that the consultant's report is unopposed and the highway department is satisfied that a competent and comprehensive study was made, great weight will be attached to it; (2) the detail with which groups other than the consultants have studied the factors involved may be influential in the degree of importance attached to their recommendations, especially if they are opposed to the final recommendation of the consultant; (3) the size and cost of the highway may determine the willingness of the highway department to reexamine the report in any given instance; (4) a necessity for prompt action because of the limited availability of federal funds often argues against a reevaluation which the highway department would otherwise be willing to make; (5) the delay which

222 As a branch of government, the Department of Highways must be alert to the reactions of local people upon pain of possible political repercussions in the affected area. Interview With City Official, June 23, 1959. A state highway official stated that the road program will not move in an urban area unless the prior approval of local officials is obtained. Interview, in Harrisburg, June 24, 1959. It was also reported that the Institute of Traffic Engineers regarded the support and cooperation of local groups as essential to meeting the time goals of the federal-aid programs, particularly the Interstate System. American City, Nov. 1956, p. 17.

223 See note 258 infra and accompanying text.

224 Extended study including reconsideration by a consultant was devoted to a dispute over an area of the Schuylkill Expressway. Baker, Report to Governor Fine; Re: Location of the Schuylkill Expressway in the Vicinity of Fairmount ParkZoological Gardens, Sept. 2, 1953. There were four major areas of contention: (1) the Fairmount Park Commission and many local citizens were reluctant to have a major highway run through Philadelphia's park lands; (2) a West Philadelphia group wanted an extension that would service their area; (3) certain influential members of the Fairmount Park Commission were especially disturbed about the location proposed for the area of the zoo-numerous proposals were studied and restudied; and (4) the Germantown, Mt. Airy and Chestnut Hill Improvement Association vigorously opposed the proposals for the Roosevelt Boulevard Extension which was to pass through an area of the city known as Nicetown. Interview With Former Planning Official, Aug. 21, 1959. The objections and alternative proposals of these groups were all before the Department of Highways when it made its various decisions.

It should not be concluded that all local reaction is unfavorable. While in most instances the people whose property is to be taken will be displeased (this itself is not invariably true; some people are happy to be paid for their property and given an opportunity to move out of an area), there are clear instances in which local people are favorable to the highway location either because it will relieve pressure of through traffic on their overburdened local roads, Interview With Local Official, in Lower Merion Twp., Pa., Aug. 10, 1959, or because the facility will directly serve their needs. Interview With Local Official, in Upper Merion Twp., Pa., Sept. 10, 1959. But greater attention is focused on those who dislike a location because of their greater vociferousness.

225 Interview With State Highway Official, in Harrisburg, June 24, 1959. 
reconsideration involves may also weigh heavily because of the expected increase in land values in the area of the proposed location; (6) as regards the complex exercise of judgment involved in weighing all the interacting planning factors discussed above, unless there is some indication that one of these factors, e.g., the location of proposed schools, is of particularly critical importance or that the consultant was lax in his consideration, the department will not extend its review beyond the broad over-all balance of cost, availability of funds, design, existing land use, highway-user benefits and relation to the overall highway needs of the state. ${ }^{226}$

An example of the ways in which various factors may play upon the degree of consideration which the highway department will give to recommendations at this stage is provided by the Mid-County Expressway. In that situation the citizens of Delaware and Montgomery Counties, Pennsylvania, became aware ${ }^{227}$ that a proposed highway was under study by the state highway department's consultants and that a route which would cut through a developed area was being given favorable consideration. ${ }^{228}$ Fear that many residences would be affected by the route which speculation indicated that the consultant would propose aroused a number of groups to oppose the selection of that route, and their unity of interests eventually led to a combination of these groups into one large opposition organization. This group, through voluntary contributions, conducted its own location survey-even using housewives to make sample origin and destination studies and traffic counts ${ }^{228}$-and on the basis of this survey compiled a report in which an alternate route was recommended. Their report was submitted to the state highway department shortly after the consultant's final report. ${ }^{230}$ Before and after its submission numerous petitions of local residents called on the highway department either not to adopt the route believed to be in favor or to adopt the route proposed by the opposition report. 231 At an unprecedented meeting held by the request of state highway officials, representatives of the interested local citizens gathered and were informed of the views of the department and of its refusal to accept the alternate proposed by the combined civic group, ${ }^{232}$ then, in the face of this opposition and of a challenge to the consultant's right-of-way cost estimates for the various alternates considered, the state highway department selected the route recommended by the consulting engineer, on the grounds that it best served highway-user needs. ${ }^{233}$ Subsequently, the

226 Ibid.

227 One source indicated that the information had been obtained from the district engineer. Another reported that it came by word-of-mouth from a private citizen with advance information. Interview With Private Citizen, Aug. 5, 1959.

228 Upper Darby News, Pa., Aug. 2, 1956.

229 Interview With Local Resident, Aug. 7, 1959.

230 Ibid.

231 Interview With Local Resident, Aug. 5, 1959.

232 Upper Darby News, Pa., Jan. 31, 1957.

233 Philadelphia Evening Bulletin, July 10, 1957, p. 1, col. 8. 
Bureau of Public Roads expressed dissatisfaction with the consultant's report, especially with regard to the estimated right-of-way costs, ${ }^{234}$ and a new firm of consultants was employed to make a restudy. ${ }^{235}$

If state funds alone are to be employed, the highway department's decision upon a single route at this time is conclusive. ${ }^{236}$ Where federal aid is contemplated, the approval of the Bureau of Public Roads will now be sought-final approval of the project ${ }^{237}$ in cases where the Federal-Aid Highway Act does not require a public hearing, ${ }^{238}$ informal and tentative approval where a hearing is required. ${ }^{238}$

\section{E. The Federal-Aid Hearing}

As has been indicated, when a state highway department intends to submit plans for a federal-aid highway project "involving by-passing of, or going through any city, town, or village, either incorporated or unincorporated," it must "certify to the Secretary that it has held public hearings, or has afforded the opportunity for such hearings, and has considered the economic effects of such location." 240 The requirement has been carried over to rural areas for projects on the Interstate System, "for the purpose of enabling persons in rural areas through or contiguous to whose property the highway will pass to express any objections they may have to the proposed location of such highway." 241 The Bureau of Public Roads has explained its understanding of the purposes of the hearing:

"to provide an assured method whereby the State can furnish to the public information concerning the State's highway construction proposal, and to afford every interested resident of the area an opportunity to be heard on any proposed Federal-Aid project for which a public hearing is to be held. At the same time the hearings afford the State an additional opportunity to receive information from local sources which would be of value to the State in making its final decision as to which of possibly several feasible detailed locations should be selected." 242

The extent of the area which will be made the subject of any one hearing is not fixed by the statute and in fact varies considerably depending upon

234 Interview With Bureau of Public Roads Official, in Harrisburg, Aug. 3, 1959. 235 Interview With State Highway Official, in Haverford, Pa., July 30, 1959.

236 See discussion in text accompanying notes 71-75 supra.

23723 U.S.C. $\$ 106$ (1958).

23823 U.S.C. \$128 (1958).

239 Interview With Bureau of Public Roads Official, in Harrisburg, Aug. 3, 1959. It should be remembered that officials of the Bureau have communicated their ideas to the state highway department from the outset. See text accompanying note 207 supra.

24023 U.S.C. $\$ 128$ (a) (1958).

241 Ibid.

242 Bureau of Public Roads, Policy and Procedure Memorandum 20-8(1), June 16, $1959, \S 2(\mathrm{c})$. 
the development of the area in question. In Pennsylvania there have been hearings on stretches two and twenty-five miles long. Reactions to and evaluations of the hearing requirement are diverse. Some officials interviewed took the position that the requirement is part of a natural and salutory evolution toward according greater consideration to the views of the lay public. ${ }^{243}$ They found advantages in its possibility of uncovering previously unconsidered factors and its opportunity for highway officials to explain and justify their decisions. Other persons interviewed considered the primary usefulness of the hearing to lie in providing a forum where dissatisfied local elements might have their say, the direction and magnitude of local reaction might be sounded out, and the highway department might attempt to muster public support. ${ }^{244}$ One frequently expressed criticism was that there are few real guidelines as to precisely what purpose the hearing process is to serve. ${ }^{245}$ Few people interviewed were able to give any meaningful definition of the term "economic effects." 248 The closest approximation seemed to be the elements discussed above under the categories of economic factors and sociological considerations. ${ }^{247}$

Before turning to the actual conduct of the hearings a consideration of the nature of information which is accessible to interested persons prior to the day of hearing is pertinent. State highway officials indicate that the current policy is to make available to the public all information that the Department of Highways has at its disposal. ${ }^{248}$ But it is relatively clear that this policy is of recent origin and that previously a policy of secrecy prevailed. ${ }^{249}$ Vestiges of the old regime still remain within the highway

243 Interview With State Highway Official, in Harrisburg, June 24, 1959; With Bureau of Public Roads Official, July 18, 1959.

244 Interviews With State Highway Officials, in Harrisburg, June 24, Aug. 7, 1959; With Local Official, June 16, 1959.

245 Interviews With State Highway Official, in Harrisburg, June 24, 1959; With Local Official, June 16, 1959; With Official of Interest Group, June 22, 1959.

246 Among those interviewed a number expressed their inability to do so. Interviews With Two State Highway Officials, in Harrisburg, June 24, 1959; With Bureau of Public Roads Official, in Harrisburg, Aug. 3, 1959. The Bureau of Public Roads gives the following definition: "the benefits or losses both to the motorists using the proposed improvement and the overall community affected thereby." Policy and Procedure Memorandum 20-8(1), June 16, 1959, § 3(d).

247 See text following note 198 supra.

248 Interviews With State Highway Officials, in Harrisburg, June 23, 24, July 30, 1959; With Former Officials, Aug. 4, Sept. 2, 1959. For a discussion of the information made available to private individuals in $W$ isconsin and their opportunities for influencing the decision see Vlasin, Property Ozoners' Problems and Legal Information They Need in Land Acquisition for Highways, 1959 WIS. L. REv. 632.

249 Interviews, Aug. 14, 1959 (local resident who complained that even when attending public meetings no additional information or justification for positions adopted by the department was presented), Aug. 12, 1959 (local resident who complained of lack of justifications given for positions adopted). The Pennsylvania legislature has enacted a "right-to-know" statute relating to disclosure of governmental information, $\mathrm{Pa}$. Laws 1957, act 212, but in an opinion dated August 30, 1957, the Attorney General of the Commonwealth indicated to the Secretary of Highways that most of the highway department's data would not be covered. Among the categories which he deemed excluded were: "Information as to route locations, traffic data, cost data, etc., contained in engineering reports prepared by Consultants for proposed highway projects;" and "Detailed locations of contemplated highway construction prior to authentication of condemnation plans by the Governor." 
department. ${ }^{250}$ A current example concerns the restudy of alternates for the Mid-County Expressway undertaken by consulting engineers hired by the department in 1958.251 The department wrote into the consultant's contract a clause prohibiting the disclosure of any information relating to his study. ${ }^{252}$ Officials of the Department of Highways also refused to discuss any matters relating to this highway. ${ }^{253}$

One practical obstacle which faces any party seeking information is a lack of knowledge as to what information is available and who can provide him with it. The amount of data accumulated pertaining to a given highway is voluminous, and highway officials are reluctant to allow persons to rummage indiscriminately through their files. ${ }^{254}$ Interest groups, through placing personnel on various official and quasi-official committees are usually well informed of the progress on a given highway, but in contrast, persons who lack such early inside information may find a number of considerations - such as an alternative which has been rejected without detailed studyforeclosed to them by the time they learn even that a highway is contemplated. ${ }^{255}$

250 Interviews With Officials of Interest Groups and Private Individuals, July 29, Aug. 6, 1959.

251 See note 235 supra and accompanying text.

252 The clause read: "The engineer shall attend closed meetings called by county and municipal authorities to ascertain their views; however, he shall not divulge his opinions or views to such authorities, the public or press." Philadelphia Evening Bulletin, May 11, 1958, p. 3, col. 6.

253 Interviews With State Highway Officials, in Haverford, Pa., June 23, July 30, 1959. One method by which the district engineer's office can avoid answering questions is to reply that the consultant has all available information and that the latter's report is submitted directly to the central office.

Persisting opposition to an open-records policy is defended on grounds (1) that local citizens will be unnecessarily aroused and disturbed by revelation of tentative proposals which may never come to fruition (ibid.), and (2) that certain persons will exploit advance notice for speculative purposes, either by manufacturing a record to support claims for excessive compensation or by buying cheap to sell at high prices after materialization of the highway plans. Interviews With State Highway Officials, in Harrisburg, June 24, 1959, and Former State Highway Official, Aug. 4, 1959. (Incidents indicating the impact of a major highway on land values have been reported. Before the advent of the Schuylkill Expressway one 40-acre farm in Upper Merion Township, Pennsylvania, sold for $\$ 24,500$. Recently 33 acres of the same farm were sold for $\$ 16,000$ per acre. Interview, Aug. 12, 1959.) However, many highway officials indicated that the incidence of the former kind of speculation is limited and that when it does occur, it is sufficiently obvious that it can effectively be combatted in the award of damages. Interview With State Highway Official, in Haverford, Pa., July 30,1959 . It has been said that especially in rural areas there is no opportunity to engage in sham transactions to boost the price. Interview With State Highway Official, in Haverford, $\mathrm{Pa}$., June 23, 1959. As to the latter type of speculation, as has been pointed out by a local citizen, Interview, Aug. 7, 1959, a system which makes information available equally and at the same time to all persons on the market is probably best suited to obviate this danger.

254 Interview With State Highway Official, in Haverford, Pa., July 30, 1959.

255 Interview With Local Citizen, Aug. 5, 1959. One official of a local agency expressed the same complaint about the Schuylkill Expressway: by the time the plans were presented to the Fairmount Park Commission they were so firmly fixed that highway officials were unwilling to change their thinking. Interview, Aug. 12, 1959. 
Notice of the hearing itself is officially published in the "legal notices" section of the local newspapers. ${ }^{256}$ More recently the inadequacies of this device have been recognized and attempts have been made to communicate more meaningful and more accessible information to the public in the form of news stories containing detailed explanations of the hearing, descriptions of the matter to be considered, and maps of the proposed route to be presented.257 The department sends registered letters to local officials and to the major unofficial interest groups. It is also true that, to a limited extent, notice of activity in relation to a highway may come to the attention of local people by informal means, such as observation of consulting engineers staking out or walking proposed locations. ${ }^{258}$ But there can be no doubt that their lack of adequate timely knowledge puts these people at a very serious disadvantage at the hearings ${ }^{250}$ as against the department of highways and the organized interest groups. ${ }^{260}$

Significantly, hearings are often held during the daytime. The effects of this practice, precluding most working men from attending and not unusually forcing housewives who do attend to leave in mid-meeting to provide for their families, have led to severe criticism on the part of many local residents. ${ }^{261}$ The standard procedure in Pennsylvania ${ }^{262}$ is first to

256 One local citizen noted the problem posed in the Philadelphia area by publishing the legal notices in the major newspapers but not in the small community papers. He complained that local people would never scan the mass of legal notices in the larger papers. Interview, Aug. 14, 1959. Another citizen interviewed was pronounced in his objections to the lack of any real efforts to notify all interested parties. Interview, Aug. 12, 1959. One leading opponent of a local highway had never been aware that a federal-aid hearing was held. See note 262 infra.

257 "[In addition to the formal notice, the hearing] shall also be publicized through other means, such as news releases to newspapers and radio and television stations, so as to provide reasonable assurance that the notice will come to the attention of all interested and affected persons. The use of graphic illustrations is desirable. . ." Bureau of Public Roads, Policy and Procedure Memorandum 20-8(1), June 16, 1959, $\S 4(\mathrm{~b})$.

258 Interview With State Highway Officials, in Harrisburg, June 24, 1959. The incidence of such informal notice would appear to be greater in rural areas than in urban ones, where the consultants often have sufficiently detailed plans at their disposal to render unnecessary, until a very late stage in the process, the actual walking of the routes. Interview With Consulting Engineer, in Philadelphia, Aug. 19, 1959.

259 Some of the people at the Delaware Expressway hearing, August 26, 1959, complained that they lacked enough information to ask questions. For a graphic description of the impact of a proposed highway on local people and their difficulties in getting information about the plans see Praeger, Extinction by Throughway, Harper's Magazine, Dec. 1958, p. 61.

260 Representatives of the interest groups are usually able to make well organized presentations of their positions. Observations of Hearings, in Philadelphia, June 17, 1959 (Gustine Lake Interchange), and Aug. 26, 1959 (portion of Delaware Expressway).

261 Hearings in Philadelphia, Aug. 26, 1959 (portion of Delaware Expressway).

262 Most of the material in this paragraph is the result of observation of two hearings in Philadelphia, June 17, 1959 (Gustine Lake Interchange), and August 26, 1959 (portion of Delaware Expressway), and reading of transcripts of two other hearings, August 15, 1956 (York Springs Interchange), and December 7, 1956 (Schuylkill Expressway and Roosevelt Boulevard Extension). (This latter hearing came at a very late stage in the process, construction of other sections being well advanced, and despite the earlier opposition, see note 224 sipra, no opposition was expressed at the hearing. One of the early leaders of the opposition was unaware that such a 
request the entering of appearances. The appearance list is no mere technicality, since it is used to determine the order of recognition for those in attendance. ${ }^{203}$ The hearing officer, a member of the state Attorney General's staff, opens with introductory remarks, a brief explanation of the purpose of the hearing, and a reading of proof of notice and the federal statutory requirement. Although the proceedings are informal-testimony is not taken under oath-a tape-recorded transcript of the entire course of the meeting is made. An engineer is first called to explain briefly the state's proposal, usually presenting justification in very general terms. Local officials are called who generally state that the local government approves the state's proposal. Then the hearing officer calls, in order, those persons who have entered their appearances. Representatives of the interest groups, being familiar with the hearing procedure, have usually managed to sign the appearance list first, and the next stage of the hearing becomes a presentation of a series of prepared statements by these organized groups. Considerable dissatisfaction is often engendered among the local people who have attended the hearing to present their views and to hear those of their friends and neighbors. ${ }^{264}$

At the hearings witnessed by the authors, decidedly little information was made available to those in attendance. ${ }^{285}$ In numerous instances when specific information was requested, the answer was usually given that the information was not available, ${ }^{266}$ or would be misunderstood; ${ }^{207}$ in some cases no answer at all was given. There was a tendency for the people attending the hearing to mistake the purpose of the proceedings and to raise questions relating to their own particular properties, despite attempts by the hearing officer to indicate that this was not a proper subject for discussion. ${ }^{288}$ At one hearing, several years ago, the hearing officer had taken

hearing had been held. Interview, Aug. 5, 1959.) The writers had informal discussions with various state highway officials present at the hearings attended, and the conduct of the hearings was also a subject discussed in interviews with officials in Harrisburg, June 24, 1959.

203 The list also assists the stenographer in preparation of a transcript.

264 At a hearing on a portion of the Delaware Expressway, August 26, 1959, local people in attendance began to mutter after the first half hour of prepared statements. Dissatisfaction grew until a number of people spoke out requesting the opportunity for "some of our people" to be heard.

265 At the hearing on a portion of the Delaware Expressway, August 26, 1959, a request was made that the maps be displayed to the public before the hearing was adjourned. Slides of the various sections had been shown earlier in the hearing, and the hearing officer twice declined to make the maps available until after the hearing had adjourned, when one of the state officials would be able to explain them. When the maps were finally shown, they were rested against a wall approximately three feet from the floor in a hallway, and many of the people were unable to see them in detail.

266 Hearing On The Gustine Lake Interchange, in Philadelphia, June 17, 1959.

207 A leader of the opponents of the Roosevelt Boulevard Extension of the Schuylkill Expressway indicated that the final answer given them was that as laymen they could not understand the technical problems involved. Interview, Aug. 5, 1959.

208 One possible cause of the confusion is misunderstanding on the part of some reporters over the mass media. A radio broadcast described the December 10, 1959, hearing on the Delaware Expressway as a forum for discussing condemnation of the 
steps to guide the course of proceedings by directing questions to the persons who testified, attempting to get them to expand upon and to explain their reactions, ${ }^{269}$ but in the more recent hearings the presiding official played a more passive role. Some tendency was observed of the local citizens to be reluctant to stand before the crowd and express their views. ${ }^{270}$ In contrast, at at least one hearing, a number of political candidates were among the speakers and they made their candidacy apparent. ${ }^{271}$

After the hearing the state highway department reviews the transcript and prepares a resume of the portions of the record it considers important. ${ }^{272}$ Despite the substantial opposition voiced at a number of hearings, the department usually does not alter its highway location plan or even order restudies at this time but rather leaves to the Bureau of Public Roads the decision of whether any reconsideration is appropriate. ${ }^{273}$ The transcript and the state's resume are forwarded to the Bureau's division engineer, whose office, having played an active role throughout the process, is generally already aware of the information the transcript will contain both in support of and in opposition to the state's proposal. (In fact, the Bureau often sends a representative to observe and perhaps to participate in the hearing.) 274 Engineers on the staff of the division engineer review all of the transcripts and evaluate the proposal which the state has submitted,

area involved. At a hearing on the Gustine Lake Interchange, in Philadelphia, June 17, 1959, a number of people requested information about the effect on their individual properties. The incidence of such inquiries was also noted during interviews. Interviews With Bureau of Public Roads Official, July 18, 1959; With State Highway Officials, in Harrisburg, June 24, 1959. At a public hearing on the Delaware Expressway, November 19, 1958, the principal concern of the homeowners was the timing of condemnation and the method of determining the price for compensation. Most of those attending were resigned to losing their homes.

269 Hearing Before Pennsylvania Department of Highways on York Springs Interchange, Aug. 15, 1956 (transcript).

270 Observation of Hearings, in Philadelphia, Aug. 26, 1959 (portion of Delaware Expressway). One individual made an impassioned plea for anyone who had any ideas to stand up and speak. He stated that the highway officials were only there to serve them, but that in the absence of some statement of local sentiment, the highway officials would be free to do as they chose. He described the hearings as part of the democratic process. There was little reaction to his pleas.

271 Observation of Hearings, supra note 270.

272 Interview With State Highway Official, in Harrisburg, June 24, 1959. It is unusual for unanticipated opposition to appear at a hearing. Interview With State Highway Official, in Haverford, Pa., June 30, 1959. However in the Delaware Expressway hearing, supra note 271 , opposition to the location of an interchange on a particular street came as a surprise. Interview With State Highway Official, in Philadelphia, Aug. 26, 1959.

273 Interview With State Highway Official, in Harrisburg, June 24, 1959.

274 "To provide coordination with the State highway department in carrying out the provisions of Section 128 [23 U.S.C. $\S 128$ (1958)], it is desirable that the division engineer or his representative attend public hearings as an observer. While in attendance at a public hearing the division engineer, or his representative, may properly explain procedural and technical matters covered by Federal-aid laws and regulations, but in no case shall he indicate a preference for any proposal advanced by the State highway department or by others." Bureau of Public Roads, Policy and Procedure Memorandum 20-8(1), June 16,1959, $\$ 5(\mathrm{~b})$. 
its justifications and any objections which were raised. ${ }^{275}$ The Bureau applies much the same standards as do the consultants and state highway department engineers. All of the technical data is reviewed by the Bureau's staff and consideration is given to estimated cost in relation to anticipated benefits, primarily in terms of highway users, but also in terms of nonusers. Decisions in relation to what have been designated economic factors and sociological considerations are evaluated against the often broader perspectives of the Bureau personnel. ${ }^{276}$

Since the Bureau has maintained constant observation and consultation and has indicated approval for the state's proposal to go to hearing, there is not much likelihood that the project will be halted at this stage unless a valid unforeseen objection has been raised. One Bureau official made the statement that he could not recall a satisfactory alternative proposal having been prepared and presented by a private group, ${ }^{277}$ although several such alternatives had led the Bureau to order a restudy. ${ }^{278}$ The division engineer, if he approves, may authorize the state to proceed with the development of final design, condemnation and actual construction. ${ }^{279}$

Although this approval by the Bureau is the final stage in that part of the creation of a highway which this Note considers, obviously a great deal remains to be done. The consulting engineer makes a final design study incorporating all of the recommendations which the Bureau may have made and any that the state may consider proper to which the Bureau has given approval. The final design is a refinement of the preliminary design and sets the specifications of the highway in the most minute detail. ${ }^{280}$ The state condemns the right-of-way, ${ }^{281}$ construction bids are received and ultimately a contract is awarded and construction begins. 1959.

275 Interview With Bureau of Public Roads Official, in Harrisburg, Aug. 3,

276 Interview With Bureau of Public Roads Official, July 18, 1959.

277 Interview, Aug. 3, 1959. An influential local citizen indicated doubt that private individuals could ever prepare feasible alternatives because of the expense involved. Interview, Aug. 12, 1959. However, on the Roosevelt Boulevard Extension of the Schuylkill Expressway an engineer was employed, compensated by public subscriptions, to draw up an alternate to the state's proposal. The alternate prepared was rejected by the state as failing to serve the needs for which the state plan was designed to provide-it lay outside the city. Interview With $A$ Leader Of The Opponents, Aug. 14, 1959.

278 Interview With Bureau of Public Roads Official, in Harrisburg, Aug. 3, 1959.

279 Bureau of Public Roads, Policy and Procedure Memorandum 20-8(1), June 16, 1959, $\S 5$ (c). Bureau of Public Roads, Administrative Memorandum 1-10.2, Aug. 5, 1957, provides specific delegations and subdelegations of authority.

280 Interview With Consulting Engineer, in Philadelphia, Aug. 19, 1959.

281 Statutory provisions governing condemnation procedures in Pennsylvania are found in PA. Stat. ANN. tit. 36, $\$ \$ 670-301$ to -308 (Supp. 1958). Special modes of proceeding are also prescribed for taking under particular statutes. See, e.g., PA. Stat. Ann. tit. 36, \$2391.8 (Supp. 1958). Highway Research Bd., Spectal Report 32, Condemenation of Property for Hrghway Purposes (Nat'l Academy of Sciences-Nat'l Research Council Pub. No. 603, 1958), provides a survey of the existing state law and presents proposals for the ideal statutory scheme. Pa. H.R. 2388 (1959), provided a completely revised condemnation procedure for Pennsylvania, but it was not enacted. For a step-by-step outline of the condemnation process from the perspective of the land-owner, see Philadelphia, Pa., Dep't of Commerce, Condemnation Procedures for the Delaware Expressway (1958). 


\section{Evaluation of the Existing Procedures and the Roles of the Various Grouts}

The main purpose of this Note has been description of the actual practice of the highway planning process, tracing the history of the road from its origins to the stage at which a final decision as to its location and design has been made. Stepping out of this temporal perspective now, we may offer a few tentative evaluative comments, less in the nature of conclusions than of formulations of problem areas for consideration.

\section{A. The Active Role of the Bureau}

The veto power lodged by Congress in the Bureau of Public Roads ${ }^{282}$ is consistent on its face with either the active role which the Bureau currently plays, making its influence felt in decisions of all kinds at all phases of the process, or with the more reserved and passive function only of determining that the estimated costs of any project are in line with the project's expected service of national highway needs. ${ }^{283}$ Yet the tenor of the legislation may imply a preference for the latter posture, ${ }^{284}$ and suggestion has been made that more discretion be left to state and local officials. ${ }^{285}$ While the very substantial character of the national investment involved ${ }^{288}$ clearly justifies the Bureau's close scrutiny of expenditures relative to over-all transportation benefits, the propriety of participation in more detailed local policy choices by a federal agency insulated from local perspectives and pressures is open to question. ${ }^{287}$ Yet in the complex of elements surrounding highway planning it is particularly difficult to distinguish "local" from "national," since any decision may represent precisely the striking of a balance between components of the two, and for this very reason a creative exchange of ideas between planners of wider and narrower viewpoints may be appropriate. ${ }^{288}$ But if the Bureau is to take this role at all, it is most efficient that the Bureau take it-as it now does-early, both so as to better understand the reasoning of all mediate

28223 U.S.C. $\$ \S 105,106$ (1958).

283 See 23 U.S.C. $\$ \$ 103,121$ (1958).

28423 U.S.C. $\S \S 105,106$ (1958). The statutory words are "the State highway department . . . shall submit to the Secretary for his approval."

285 See 2 Advisory Comm. on Local Government, Comm'n on IntergovernMental Retations, Locat. Government 3, 43 (1955).

286 The appropriation for the Interstate System alone for the fiscal year 1961 is $\$ 2$ billion. Act of Sept. 11, 1959, 73 Stat. 611.

287 The Highway Research Board has in process of preparation two studies relating to this problem: Intergovernmental Relations in State Highway Legislation and Federal Aid Provisions in State Highway Laws.

288 See 1 Study Comm. on Federal Aid to Highways, Comm'n on Intergovernmental Relations, Federal Am to Highways 2, 4, 26 (1955). See also 2 GovernMENTAL AfFaIRs INSTITUTE, COMM'N ON INTERgovernMENTAL RELATIONS, The Impact of Federal Grants-in-Aid on the Structure and Functions of State AND LOCAL GoverNMGENTS (1955). 
decisions made en route to a conclusion which it must approve, and so as to save the very expensive business of restudy which would be necessitated if state officials rejected at the beginning of the process considerations which the Bureau later found controlling. Moreover, there is evidence that the influence of the Bureau sometimes operates to protect local community interests from pressuring by the state, as well as to present a bulwark, manned by civil service personnel, ${ }^{280}$ against forces to which state highway departments, often without merit systems, ${ }^{290}$ might be vulnerable. On the whole, the present reaction of state officials to the Federal Bureau appears to be one of deserved appreciation for the manner in which that agency handles its complex and difficult task. ${ }^{291}$

\section{B. Vagueness of Federal and State Statutory Standards}

In the more technical aspects of civil and traffic engineering, highway officials, following the federal statutory mandate for the adoption of "geometric and construction" standards, ${ }^{202}$ have formulated and are employing standards capable of precise articulation. Yet in the broader sphere of socio-economic policy, where presumably the professional expertise of the engineering staffs of the Bureau and state highway departments is less to be relied on, federal and state legislation, managing no more precise directive than the charge to consider "economic effects," ${ }^{293}$ leaves agency discretion wholly at large. The Federal Bureau itself is now engaged in attempting to develop a set of evaluative criteria which will regularize the often ad hoc approach to decision in this realm, ${ }^{294}$ but it may be cogently argued that the proper forum for the debate of these sensitive matters of policy is legislative-more particularly the state legislatures. In fact, a bill introduced in the Pennsylvania General Assembly in 1959 did provide a checklist of considerations, not intended to be exclusive, for the direction of administrative judgment in highway location, ${ }^{295}$ but the section was excised in the House committee. Such a statutory prescription, working not to ossify but to guide the decisional processes of the road-planning agencies, seems desirable. Not the least of its benefits would be to control whatever tendency highway experts may have to look too narrowly to highway user features to the exclusion of such other important considerations as land use patterns as mass transportation, ${ }^{296}$ and it might also serve to discourage

28923 U.S.C. $\$ 303$ (b) (1958).

280 Results of a questionnaire conducted as a part of this project indicated that twenty-three states have some merit system while twenty-two have none.

291 Interviews, June 24, Aug. 3, 1959.

29223 U.S.C. $\$ 109$ (b) (1958).

29323 U.S.C. $\$ 128$ (1958). See notes 246,247 sipra and accompanying text.

294 Interview With Bureau of Public Roads Official, July 18, 1959.

205 Pa. H.R. 1702, § 502 (1959).

296 See Owen, Cities in the Motor Age 10-13, $31-41$ (1959) ; Howard, Tomorrow's Highways, 47 NAT'L MUNIC. Rev. 378 (1958); Fordham, Urban Renewal In Metropolitan Context, Fifth Annual Wherrett Lecture on Local Government, Institute of Local Government, University of Pittsburgh (1959). 
the inclination of department officials to cloak their conclusions in an aura of professional expertise intended to foreclose counterargument. ${ }^{297}$

\section{Federal Time Limitation and State Advance Planning}

The two-year time limitation on federal highway appropriations ${ }^{298}$ can have a number of harmful effects in states like Pennsylvania where little long-range planning is done. ${ }^{299}$ Complaint has been made that the limitation rushes decision at a pace which fails to allow careful evaluation of all relevant considerations, ${ }^{300}$ and that it has been used as a tool to force dissenting local groups to relax their opposition to formulated state plans under threat that the delay entailed in debate might cost the loss of federal money. ${ }^{301}$ Yet the fault in this regard lies less with Congress than with Pennsylvania. California is the leading, but not the sole, example of a jurisdiction which looks to the future in its highway planning. The state pursues its planning to the final stages, including numerous hearings and informational meetings to develop acquaintance with local attitudes and concerns, without regard to the current availability of funds. ${ }^{302}$ The highway officials of that state have been given broad powers to implement their advanced planning, even the power to condemn and prepare rights-of-way prior to plans for actual construction..$^{303}$ The advantages of this system in terms of eliminating a time-money press are clear, and other advantagesavoidance of accretion of land values, prevention of development of currently vacant land which is planned for highway uses-also follow. The California system has much to recommend it and various highway officials and private citizens look to it as the answer to one of the most perplexing current problems. $^{304}$ Pennsylvania's recently established Office of Planning and Research may be a step in this direction.

207 See note 267 supra and accompanying text.

29823 U.S.C. $\S 118$ (1958).

289 The Pennsylvania statutory frame does not provide for the development of any scheme of future growth for the highway system. A provision authorizing the designation of a path in advance of further proceedings for the location and construction of highway facilities, PA. STAT. ANn, tit. 36, $\$ 670-219$ (Supp. 1958), is reportedly never used by highway officials because of doubts as to its constitutionality. Interview, in Harrisburg, June 24, 1959. Note has been taken of the legislative cold shoulder accorded to the 1950 recommendations of the Highway Planning Commission, see note 147 supra and accompanying text, and officials have recognized that the failure of the department itself to formulate an over-all program with assignment of priorities has placed the state's procedures under severe stress in conjunction with the federal time limit. Interview With State Highway Official, in Harrisburg, June $24,1959$.

300 Interviews With State Highway Official, in Harrisburg, June 24, 1959; With Local Official, Aug. 12, 1959.

301 Interview With Private Citizen, Aug. 12, 1959.

302 See McCoy, California Highways 1958, Calif. Highways and Public Works, Jan.-Feb. 1959; Vickrey, State Raads, Calif. Highways and Public Works, Nov.Dec. 1958.

303 Ibid.

304 Interviews With Local Official, June 16, 1959; With State Highway Officials, in Harrisburg, July 18, 1959; With Bureau of Public Roads Official. Aug. 4. 1959. 


\section{Legislative Control of Highzway Designation}

Attack on the current Pennsylvania procedure which requires legislative initiation of highway projects ${ }^{305}$ other than limited access facilities ${ }^{306}$ was again warded off in the 1959 session of the General Assembly. ${ }^{307}$ Yet, despite recognition of the operation of broad policy judgments in this realm of decision-making, the noted tendency of the legislature to enact omnibus highway statutes removing from local governmental entities responsibility for maintenance of local roads, ${ }^{308}$ and to employ highways as public works projects to impress regional constituents with the benefits which their regional representatives can secure, has led most commentators to favor a scheme placing full initiative authority exclusively in administrative hands. ${ }^{309}$

\section{E. Civil Service for Department Personnel}

The lack of a legislatively established merit system for highway department employees has been severely criticized, ${ }^{310}$ and is perhaps in part responsible for the department's currently complained-of difficulty in attracting qualified personnel. ${ }^{311}$ The offered justifications (a) that many of the jobs involved-road maintenance labor, for example-do not lend themselves to civil service examination and (b) that the department's seasonally fluctuating needs preclude any rigidity in the employment scheme, ${ }^{312}$ do not seem applicable to the staff engaged in the planning phase; and a number of these and other professional posts have been placed by administrative action under civil service controls. ${ }^{313}$ The fragmentary nature of this latter scheme and the fact of its susceptibility to alteration from within, however, recommend more thoughtful legislative treatment of the problem. In this connection it is significant that the highway department traditionally employs more people and operates closer to local ground roots than any other state agency responsible for public works projects.

\section{F. The Single-Executive Secretary}

On the matter of choice between a single executive and a commission to head up a state highway department, the data made available by this Note can go no further than to suggest that the extreme complexity of the

305 Pa. Stat. AnN. tit. 36, §670-102(1) (Supp. 1958).

306 Pa. Stat. Ann. tit. 36, $\$ 2391.2($ b), (d), 2391.8 (Supp. 1958).

307 The House Committee on Highways excised $\S \S 502,503$ from Pa. H.R. 1702 (1959).

308 Interview With State Highway Official, in Harrisburg, June 24, 1959.

309 Pa. Highway Planning Comm'n, Report on Pennsylvania Highways TOdAy AND TOMORRow (1950); Automotive Safety Foundation, Report on State Highway Policies and Practice in Pennsylvania, Aug. 1, 1958.

310 See Automotive Safety Foundation, supra note 309, at 16, 17.

311 Interviews With State Highway Officials, in Harrisburg, June 24, Aug. 3, 1959.

312 Interview With State Highway Official, in Harrisburg, Aug. 3, 1959.

313 See notes 92,94 supra and accompanying text. 
elements of ultimate decision in the planning sphere seem peculiarly to invite consideration from a multiple perspective. ${ }^{314}$ Whether that kind of consideration can best be achieved at the highest level of authority or below it, in view of the need for decisions both informed and responsible, is a question to which no immediate answer appears forthcoming. ${ }^{315}$

\section{G. The Use of Consulting Engineers}

Although no state statutory provision directly authorizes the employment of consultant firms by the highway department, ${ }^{316}$ the practice has become standard for projects of any magnitude. ${ }^{317}$ Department officials, who keep a constant check on the capabilities of the various available firms, are generally able to secure competent service, and it is even reported that repeated use of the same consultants for succeeding highway projects has begun to develop a specialized road-location expertise in some of these firms. ${ }^{318}$ Since the job now done by the consultants represents the most thorough, detailed and radical operation in the decision-making process, and since very great weight is subsequently accorded to its conclusions, an ideal system might well choose to put that job in the hands of a staff permanently within public administrative control. But there seems no doubt that highway officials are correct in regarding this ideal as impracticable: even could it outbid the private firms for a sufficient corps of qualified professionals, the department could hardly afford to maintain on a continuing basis the number of persons which it requires-only sporadically -for major expressway projects. What would be both desirable and practical within the present framework is the improvement of some points of communication between the state administration and its consultants: while highway officials consistently proclaim, for example, that the consulting engineer is the agent in the process who considers local reactions, ${ }^{\mathbf{3 1 9}}$ the consultants themselves say that they have no contact at all with local groups or private individuals. ${ }^{320}$

314 The present Secretary of Highways in Pennsylvania has an engineering background; his predecessor was a lawyer. The job of heading up an agency which employs approximately 15,000 persons is obviously one demanding considerable administrative talent.

315 A bill to create a commission was introduced in the 1959 session of the Pennsylvania legislature, Pa. S. 25 (1959), but was not enacted.

316 But see 23 C.F.R. $\$ 1.8$ (b)(3) (1958) (limitation on the use of consulting engineers).

317 Interview With State Highway Official, in Harrisburg, June 24, 1959. It was reported that the United States Comptroller General in a report to Congress was highly critical of the use of consulting firms in Pennsylvania because of the added expense involved. Philadelphia Inquirer, Dec. 22, 1959, p. 7, col. 3.

318 Interview With State Highway Official, in Harrisburg, June 24, 1959.

319 Interviews With State Highway Officials, in Harrisburg, June 24, 1959, in Haverford, Pa., July 30, 1959.

320 Interviews With Consulting Engineers, in New Jersey, Aug. 4, 1959, in Philadelphia, Aug. 13, 19, 1959. 


\section{H. The Roles of Local Governments and Local Government Agencies}

Local governmental entities, acting through their legislative and executive organs, stand ideally situated to perform two indispensable functions in the highway location process. Their proximity to and knowledge of the affected private interests within their respective bailiwicks makes them excellent natural channels both for the dissemination of highway information from the state authorities to the public ${ }^{321}$ and for the funnelling of public reaction back to the state authorities. ${ }^{322}$ Second, they are the only official bodies within the decision-making process which are not exclusively highway-oriented: they can bring to bear a perspective which encompasses sensitively the multiple effects of a road on total community structure. How to implement these crucial functions in terms of power structure is a difficult issue. Under Pennsylvania's statutory requirement of municipal approval for the location of in-city highways, ${ }^{323}$ it is reported that the cities' actual influence on decision is less than their de jure veto would indicate, since the state's control of funds-and of access to federal funds-is an effective instrument of pressure.324 On the other hand, if the planning agency of a township which does not have the veto power learns early enough of a highway proposal, estimates as nearly as possible the points at which the highway will enter and leave its area, engages in detailed study and evaluation of locational features, concludes upon a precise route, and prevails upon property owners along that route to restrict development of their properties, the likelihood that the state can be persuaded to adopt the route is very great. ${ }^{325}$ This means, in effect, that the practical impact which a local authority will have depends in large part upon the effort and foresight which it brings to the locational process-a generally salutory situation. But that impact will also depend in part upon how early the authority learns of the highway plans, since once the state's own highway-location machinery is set in motion it cannot be delayed to enable the local groups to perform their studies. This latter fact makes particularly unfortunate the tendency of the department to postpone contacting these official local organsespecially those which lack the veto-until rather late. The whole dimension of phasing, of how soon in the evolution of a highway an event occurs or an interest is heard, is a pervading, critically disturbing problem throughout road planning. A suggestion of extensive early discussion is likely to be met-and, in part, legitimately-with the response that, until ideas are more precisely formulated and studies made, there is nothing meaningful to discuss. But the very process of formulating ideas and conducting studies involves the making of decisions, and restudy is so expensive that those

321 Interview With City Official, June 23, 1959.

322 See Owen, Cities in the Motor Age 118-19 (1959).

323 Pa. Stat. ANn. tit. 36, §§ 670-523, -544, -545 (Supp. 1958).

324 Interviews With Local Official, Aug. 12, 1959; With Former Local Official, Aug. 21, 1959.

325 Interviews With Consulting Engineer and Official of Interest Group, Aug. 4, 1959; With Planning Official, Sept. 10, 1959. 
decisions are difficult to unmake. Because the process is one of refinement by elimination, many intermediate judgments have become effectively final -in the minds of the official planners-before the plan has so far crystallized as to focus the issues for debate. At the least, although their access to the deciding agency may of necessity be delayed, local authorities and private interests should be kept continuingly informed from the outset, by appropriate publications or news releases, of the status, progress and direction of the planning, so that they are able to do what they can, independently of the agency, to prepare for the time when their voice will be heard.

Returning more particularly to the municipalities, there remains the problem of the veto. Although practical politics may cause ultimate questions to be seldom reached, the answers to those questions affect lessthan-ultimate questions as well (the obviously greater respect accorded by the highway department to local authorities having the veto furnishes an example) and the Pennsylvania legislation does make an ultimate allocation of power. The alternative allocation-not requiring municipal approval for highway location within municipal bounds-would greatly reduce the value of the municipality as a channel for the focusing of private reaction to highway plans, since it is apparently impossible to restrain individuals from presenting their views as strongly as they can to the agency with ultimate power to decide. More fundamentally, it would represent a decision, in the last analysis, to sacrifice a complex of local needs which is strong enough to motivate the exercise of a veto to the needs of the traveling public and the state at large. ${ }^{326}$ That sacrifice can of course be made under the current Pennsylvania scheme as well, since the General Assembly can itself override a municipal veto, ${ }^{327}$ but the chance of the General Assembly taking affirmative action-especially action in an individual conflict situation and in contravention of a standing general legislative policy-is, for political reasons, very slight. In view of the enormity of the municipal interests concerned, perhaps indeed only the state legislature, not the executives of the Department of Highways, should be able so to override municipal objection. We suggest only that the wisdom of the present scheme is debatable.

Less debatable, however, seems the unwisdom of vesting a veto in some one or more specialized municipal agencies, as, in Philadelphia, the Art Commission ${ }^{328}$ and the Fairmount Park Commission. ${ }^{329}$ More reasonably (and what seems in fact to be a developing procedure today) one agency (the Department of Streets, in Philadelphia, fills the role) ${ }^{330}$

326 See University of California Institute of Transportation and Traffic Engineering, Research Report No. 29, Freeway Location Conflicts in California, 1959, for a discussion of the problems of conflicting state and local interests.

327 All municipal authority derives from the state. See Marshall Impeachment

Case, $363 \mathrm{~Pa}$. 326, 339-40, 69 A.2d 619, 627 (1949).

328 Charter $§ 5-903$.

329 Charter $\S 5-602(a)$.

330 Interview With City Official, Aug. 12, 1959. 
should coordinate all of the viewpoints of the local organs and assure that all are given adequate and balanced consideration.

\section{The Role of the Interest Groups}

The functioning of the private interest groups must be considered, in large part, as interwoven with that of the local public officials, in close connection with whom the interest groups work and whose advisory committees personnel of the interest groups often staff. The problem posed by these groups arises because (1) their continuing preoccupation with highways, their private resources, and their developed expertise make them the local factions most capable of providing effective aid to governmental highway planners, yet (2) they are interest groups-representative of a particular viewpoint which will not necessarily coincide with that of the public interest generally. ${ }^{331}$ That government will continue to rely upon the services of these groups seems both salubrious and inevitable. Two cautions should be advanced, however, which will reduce some of the danger inherent in that practice. Officials who deal with interest groups should remember that the latter do represent vested interests, and should make appropriate allowance in their appraisal of the views of the groups. Even more important, to eliminate the edge which advance insider information gives the groups, highway planning ideas should be made available to the whole public on equal terms through the mass media at the earliest date and continuously throughout the course of their development thereafter.

\section{J. The Role of the Private Individual}

From all available information, the private individual-property-owner, community resident, taxpayer-has little opportunity to influence highway location decisions. Despite assumptions of department administrators to the contrary, consulting engineers do not solicit his views. He has sometimes attempted petitions, conferences with highway officials, letters to those officials, apparently to little avail. On occasion he has sought the aid of courts, but little protection has been provided. ${ }^{332}$ In the absence of express legislative directive, the courts have refused to impose upon highway departments such affirmative procedural duties as making information available, ${ }^{333}$ and, indeed, under the vague statutory delegations, judicial

331 The Citizens' Council of City Planning in Philadelphia, see text accompanying notes 138-39 supra, is a unique exception.

332 Piekarski v. Smith, 147 A.2d 176 (Del. Ch. 1958), aff'd, 153 A.2d 587 (Del. 1959); State v. Weinstein, 322 S.W.2d 778 (Mo. 1959); Binghamton Citizens Penn-Can Route 17 Highway Comm. v. Federick, 7 App. Div. 2d 170, 180 N.Y.S.2d 913 (1958); City of Lakewood v. Thormyer, 80 Ohio L. Abs. 65,154 N.E.2d 777 (C.P. 1958), aff'd, 157 N.E.2d 431 (Ct. App. 1959).

333 Piekarski v. Smith, supra note 332; Binghamton Citizens Penn-Can Route 17 Highway Comm. v. Federick, supra note 332 . 
intervention into substantive planning decisions would be unfounded. ${ }^{334}$ The individual is relegated for the expression of his views to the public federal-aid hearings, where inconvenient hours, unfamiliar procedures and a reluctance of state engineers to answer his questions will probably baffle him, ${ }^{335}$ and where, in any event, he will find that the highway location plans have already so far jelled that those who have been in on the planning will be disinclined to change them. ${ }^{338}$ At all of these phases, moreover, he will be severely handicapped by the prohibitive cost of having those studies made which will justify his proposals, by the attitude among state planners that, as a layman, he can have little to tell them about their work, and by a continuing inability to discover precisely what is going on as the plans develop.

Should the individual have a part in the decision-making process? Numerous thoughtful objections are made to his participation. It is pointed out that highway location and design are difficult scientific subjects beyond the ken of laymen and that, once extensive popular intervention into planning is permitted, there may develop mass approval of technically unfeasible alternatives which will make valid proposals strongly unpopular

334 Determining the location of a highway represents the exercise of a combination of legislative and executive functions within the separation of powers doctrine. The factors to be considered and the decisions to be reached are not of the nature of those issues which are generally given to, or susceptible of adjudicative determination by, the regular judicial tribunals. Cf. South v. Peters, 339 U.S. 276 (1950); Massachusetts v. Mellon, 262 U.S. 447 (1923). For one whose property is ultimately taken, the opportunity to present defenses in the condemnation proceedings will provide adequate relief. PA. STAT. ANN. tit. 36, §§670-310 to -308 (Supp. 1958). As regards the earlier phases of the highway program, the Clay committee suggested that a federal highway corporation with a board of directors be established, primarily to finance the program, but also to serve as a final agency for administrative appeals. President's Advisory Committee on a National Highway Program, A 10-Year National Highway Program, H.R. Doc. No. 93, 84th Cong., 1st Sess. 23 (1955). No such organ has been established.

335 While many people argue that the hearing fails to satisfy basic standards of fairness, Interviews With Civic Leaders, Leaders of Interest Groups, and Private Individuals, June 22 , Aug. 12, 14, 1959, too often they are thinking in terms of a judicial or quasi-judicial hearing. The highway hearing is clearly not intended to fulfill those purposes, but rather ideally is a means for a two-way exchange of ideas. The problems which have arisen derive rather from the attitude with which some officials approach a hearing than from a failure of the statutory scheme to provide adequate protections. The statute might well be filled out with provisions for advance notice, accessibility of information prior to and at the hearing, and the stage in the process of decision at which hearings should be held. However until the attitude of the personnel conducting the hearings becomes more reflective of their underlying purposes, legislation will not make the hearings an effective device. Some progress has been made by the Bureau of Public Roads in its formulation of a memorandum, Bureau of Public Roads, Policy and Procedure Memorandum 20-8(1), June 16, 1959, prescribing the procedure to be employed and the goals toward which the hearing is directed. Perhaps the attitude held by Bureau officials and by some state officials will tend to filter down to the people who represent the state at the hearings.

336 The Bureau of Public Roads, Policy and Procedure Memorandum 20-8(1), June $16,1959, \S 4(\mathrm{f})$ states: "A representative of or spokesman for the State highway department should explain the proposed project, . . and alternative routes, if any, that have been considered." However, state highway officials indicated their reluctance to disclose alternatives because the people were "liable to choose up sides." Interview, in Harrisburg, June 24, 1959. 
and impede their implementation. ${ }^{\mathbf{3 3 7}}$ The greater propensity of opponents, as against proponents, to engage in oratory is pointed to, as is the inclination of persons seeking their own political or social advancement to take the lead in opposition groups. ${ }^{338}$ It is said that whenever an issue of judgment is put out before the people, they will split up into camps and fight interminably. ${ }^{332}$ The inadvisability of making information public at early planning stages is supported by the claimed danger of land speculation and by the proposition that when an individual sees a line, however tentativeand although it may be only the least likely of half a dozen alternative routes under consideration-which bisects his home, he will become unduly and prematurely panicky. 340

These arguments present points of indisputable cogency. Nevertheless there are in opposition several other seemingly cogent points.

(1) The worst evil at which a number of the arguments abut is delay. While delay is indeed a serious threat today in Pennsylvania, under the menacing possible loss of federal funds as the appropriations limit runs, delay presents no similar problems in a jurisdiction with a comprehensive, coordinated advance planning system : indeed, public hearings may there be held several years before highway construction funds become available. Even where delay is expensive, it is always only a weight on one side of the scale, against which must be balanced both the risk of less than fully deliberate judgment and the impairment of popular esteem for government which is potential in situations where individuals feel that they have been hustled out of their rights without opportunity to speak. Moreover, the premise of the arguments of delay-that a greater loss of time is involved in allowing the objecting individual to speak out early and in trying to convince or to compromise with him then, than in dragging him along unwilling through all the phases of the process, which he regards as unfair and may attempt to stall or to impede-is at best an assumption of fact which may be debated. ${ }^{341}$

337 Interview With State Highway Official, in Harrisburg, June 24, 1959. This fear is perhaps justified in part by the inclination of some persons who favor public hearings to speak of the hearing as a sort of popular vote by which a highway is given the stamp of public approval. Interviews With Leader of Interest Group, Aug. 12, 1959; With Former Public Official, Aug. 14, 1959. That this latter position is unsupportable should be evident both from the nature of the decisions involved and from the fact that Congress, while providing for a hearing, made no provision for any kind of ballot-type popular control. Cf. Bureau of Public Roads, Policy and Procedure Memorandum 20-8(1), June 16, 1959, §2(d): "The hearings are not intended to be a popular referendum for the purpose of determining the location of a proposed improvement by a majority vote of those present."

338 Interview With Former City Official, Aug. 21, 1959.

339 Interview With State Highway Officials, in Harrisburg, June 24, 1959.

340 Interview With State Highway Officials, in Haverford, Pa., June 23, 1959.

341 Where a hearing is ultimately to be held, attempt to minimize delay by keeping the public out of the process of decision until a late stage often defeats itself because the public may react so violently to a finished product in which their views, they feel, were not considered, that a restudy must be undertaken. Interviews With Bureau of Public Roads Officials, July 18, 1959. 
(2) The arguments which attribute various dangers to premature public knowledge of planning developments seem to assume that there is less to be feared in the unexplained, incomplete, unequally-accessible information that rumor and official "leaks" make public than in open, fully articulate periodic releases by highway officials. This is another debatable assumption of fact.

(3) To the extent that federal funds are involved, it appears that in large measure the argument to the merits of public participation has been legislatively foreclosed. Congress has required a public hearing which, presumably, was intended to perform some purpose ${ }^{342}$ - probably in part connected to that appraisal of "economic effects" to which the states are directed. When the public's effective functioning at those hearings is hampered by obstructive procedures and official unwillingness to divulge relevant data, the congressional purpose is being frustrated.

(4) While highway planning does involve complex technical problems of engineering, it involves also, as this Note has attempted to show, problems of judgment in community values as to which the layman may be as well qualified to speak as the professional planner. So long as planning decisions are to be made-and recognizedly they are-on grounds of the benefit or detriment to affected local groups of certain physical structures and conditions, it is illogical not to let those groups be heard on what, from their perspective, the benefits and detriments are. Nor is it altogether logical to take a position, as some highway officials apparently do, ${ }^{343}$ which at once depreciates the value of popular participation on the argument that the people do not understand what planning is about, and, at the same time, refuses to make public the substantive and procedural facts which could enlighten them.
P. L. D.
F. H. L.
J. T. V.

342 See note 240 supra.

343 Interviews, July 30, Aug. 7, 1959. 